\title{
Development of a General Aza-Cope Reaction Trigger Applied to Fluorescence Imaging of Formaldehyde in Living Cells
}

Kevin J. Bruemmer, ${ }^{\dagger, \nabla}$ Ryan R. Walvoord, ${ }^{\dagger, \nabla, \#}$ Thomas F. Brewer, ${ }^{\dagger}$ Guillermo Burgos-Barragan, ${ }^{\prime \prime}$ Niek Wit," Lucas B. Pontel, ${ }^{\|}$Ketan J. Patel, ${ }^{\|, \perp}$ and Christopher J. Chang, ${ }^{*},+,, \S_{0}$

${ }^{\dagger}$ Department of Chemistry, ${ }^{\ddagger}$ Department of Molecular and Cell Biology, and ${ }^{\S}$ Howard Hughes Medical Institute, University of California, Berkeley, Berkeley, California 94720, United States

"MRC Laboratory of Molecular Biology, Francis Crick Avenue, Cambridge CB2 0QH, United Kingdom

${ }^{\perp}$ Department of Medicine, Addenbrooke's Hospital, University of Cambridge, Cambridge CB2 2QQ, United Kingdom

Supporting Information

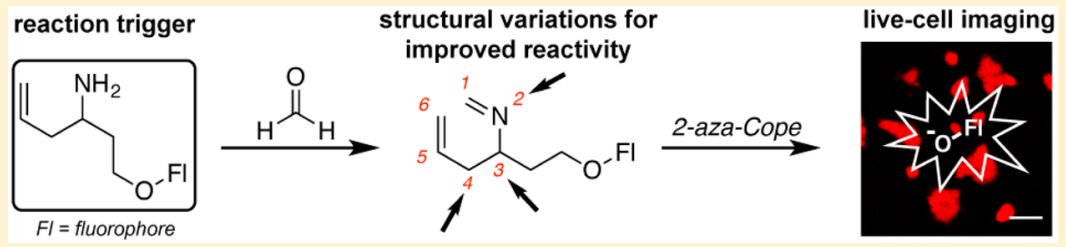

ABSTRACT: Formaldehyde (FA) is a reactive signaling molecule that is continuously produced through a number of central biological pathways spanning epigenetics to one-carbon metabolism. On the other hand, aberrant, elevated levels of FA are implicated in disease states ranging from asthma to neurodegenerative disorders. In this context, fluorescence-based probes for FA imaging are emerging as potentially powerful chemical tools to help disentangle the complexities of FA homeostasis and its physiological and pathological contributions. Currently available FA indicators require direct modification of the fluorophore backbone through complex synthetic considerations to enable FA detection, often limiting the generalization of designs to other fluorophore classes. To address this challenge, we now present the rational, iterative development of a general reaction-based trigger utilizing 2-aza-Cope reactivity for selective and sensitive detection of FA in living systems. Specifically, we developed a homoallylamine functionality that can undergo a subsequent self-immolative $\beta$-elimination, creating a FA-responsive trigger that is capable of masking a phenol on a fluorophore or any other potential chemical scaffold for related imaging and/or therapeutic applications. We demonstrate the utility of this trigger by creating a series of fluorescent probes for FA with excitation and emission wavelengths that span the UV to visible spectral regions through caging of a variety of dye units. In particular, Formaldehyde Probe 573 (FAP573), based on a resorufin scaffold, is the most red-shifted and FA sensitive in this series in terms of signal-to-noise responses and enables identification of alcohol dehydrogenase 5 (ADH5) as an enzyme that regulates FA metabolism in living cells. The results provide a starting point for the broader use of 2-aza-Cope reactivity for probing and manipulating FA biology.

\section{INTRODUCTION}

Formaldehyde (FA) is a reactive carbonyl species (RCS) that is widely utilized in industrial applications ${ }^{1}$ as well as a protein cross-linker for tissue fixation. ${ }^{2}$ Long classified as a toxin and carcinogen, ${ }^{3}$ FA exposure can occur through a variety of natural and anthropogenic sources including microbe emission, car exhaust, and building materials. ${ }^{4}$ While traditionally thought of as detrimental to living organisms, FA is an endogenously produced biological metabolite that is continuously released during essential biological pathways, including epigenetics and one-carbon metabolism. ${ }^{5}$ For example, lysine and arginine demethylase enzymes such as lysine specific demethylase $1^{6}$ and JmjC domain-containing proteins ${ }^{7}$ produce FA during epigenetic regulation of histone tails. ${ }^{8,9}$ In addition, during one-carbon metabolism, demethylation of choline metabolites en route to production of glycine releases FA as a critical onecarbon unit for the synthesis of important biological building blocks. ${ }^{10}$ Governed by a complex homeostasis involving many metabolic enzyme systems, FA reaches a steady state level of $50-100 \mu \mathrm{M}$ in the blood ${ }^{11}$ and $200-500 \mu \mathrm{M}$ intracellularly. ${ }^{12}$ Even higher resting levels of FA have been found in a variety of disease states, including neurodegenerative diseases, ${ }^{13}$ cancer, ${ }^{14}$ and asthma. ${ }^{15}$ To counteract the toxicity of FA, living organisms have developed efficient metabolizing pathways for FA. One predominant FA-metabolizing enzyme is cytosolic alcohol dehydrogenase 5 (ADH5) (also known as FA dehydrogenase and alcohol dehydrogenase 3 ), which oxidizes FA to formate through a glutathione-dependent reaction. ${ }^{16}$

The dynamics of FA production and consumption in living systems and its understudied consequences continues to motivate the development of new methods for its detection in biological specimens. Traditional detection methods for FA rely upon mass spectrometry, ${ }^{17,18}$ high-performance liquid

Received: December 2, 2016

Published: April 4, 2017 
chromotography, ${ }^{19,20}$ and preconcentration/chemical ionization, ${ }^{21}$ which are highly sensitive but require harsh conditions that are not suitable for live-specimen detection. In this context, fluorescent probes offer a promising mode of FA detection as they have been widely utilized to detect small-molecule biological metabolites through recognition or reactivity-based approaches. $^{22-25}$ Indeed, reactivity-based methods have been successfully used to visualize other carbonyl species such as carbon monoxide ${ }^{26-30}$ and methylglyoxal, ${ }^{31}$ and our lab ${ }^{32,33}$ and others ${ }^{34-43}$ have developed new FA indicators suitable for live-cell and live-animal imaging, based largely on 2-aza-Cope or hydrazine condensation reactions.

These initial reports establish the promise of reactivity-based fluorescent approaches for monitoring biological FA but leave room for significant improvement. One key challenge to address is that only a relatively small number of fluorescent scaffolds have been reported for FA detection, because the vast majority of fluorescent FA probes operate through direct modification of the dye backbone to elicit a fluorescence response. As such, efforts to improve FA reactivity and selectivity tend to simultaneously perturb photophysical properties of the dye. This synthetic limitation restricts the ability to tune excitation/emission profiles, cellular localization, and other properties independently of FA reactivity.

To address this outstanding issue, we now present the development of a general 2-aza-Cope reaction trigger with a self-immolative $\beta$-elimination linker that can be installed onto any fluorophore containing a common phenol group, enabling a wider range of fluorescent scaffolds to be functionalized for FA detection. Iterative, rational design of triggers to optimize structure-activity relationships for fast kinetics and fluorophore release on a 4-OMe-Tokyo Green (TG) fluorescent scaffold ${ }^{44}$ can be expanded to deliver a variety of fluorescent FA indicators with excitation and emission profiles spanning wavelengths across the UV to visible spectrum. We further establish the utility of these FA probes to detect changes in this RCS in living cells. Moreover, the resorufin-based congener, FAP573, gives the highest signal-to-noise response and the most red-shifted excitation/emission profile, enabling visualization of changes in the cellular metabolism of FA mediated by $\mathrm{ADH} 5$ using genetic knockout models.

\section{RESULTS AND DISCUSSION}

Design and Synthesis of a General 2-Aza-Cope Reaction-Based Trigger. Previous work from our laboratory reported FAP-1, a first-generation reaction-based fluorescent probe for detecting FA through a turn-on response (Scheme 1). ${ }^{32}$ Specifically, we developed a reactivity-dependent FA indicator through conversion of a homoallyl amine into an aldehyde on a silicon rhodamine scaffold, where control of spirocyclization gives rise to a turn-on fluorescence readout. In attempts to generalize this reaction to develop fluorescent FA probes with a broader range of excitation/emission colors and maintain good insensitivity to $\mathrm{pH}$, we were thwarted by the need to directly functionalize the fluorophore backbone and rely on often complex spirocyclization equilibria to achieve a fluorescence response. We reasoned that separating the dye scaffold and FA-dependent trigger unit into separate, independent pieces might allow for a more general strategy for developing a range of FA-responsive fluorophores. Specifically, we sought to cage phenolic fluorophores with a homoallylamine aza-Cope trigger with a self-immolative linker, envisioning that these $\mathrm{O}$-alkylated fluorophores would react
Scheme 1. Self-Immolative Aza-Cope Strategy for FAResponsive Fluorescent Probes

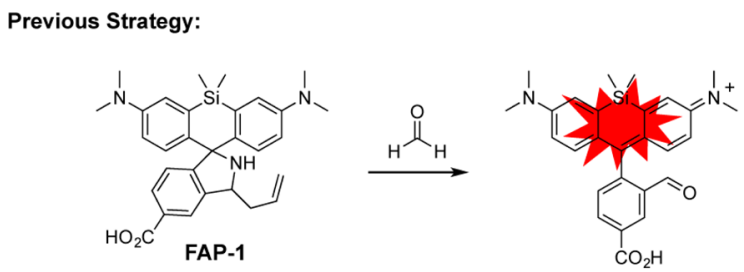

Present Strategy:

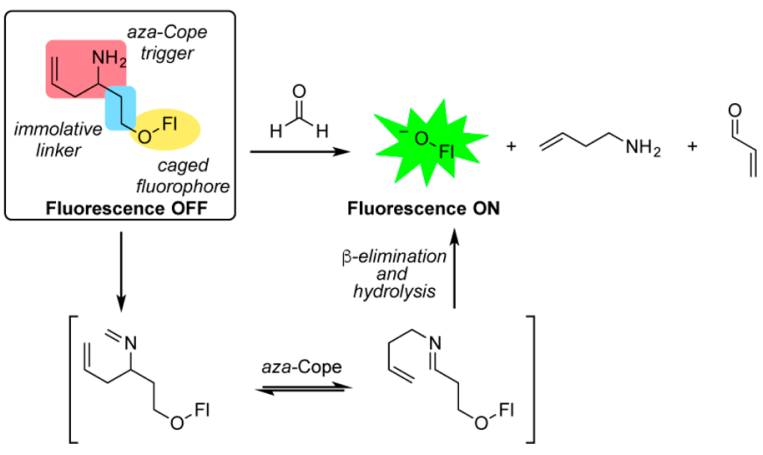

with FA through a 2-aza-Cope rearrangement to the rearranged imine. Subsequent elimination of the two carbon linker via a $\beta$ elimination would afford the uncaged phenolate an expected increase in fluorescence in addition to the homoallylamine and acrolein byproducts. ${ }^{45-48}$ Such a trigger could be applied to phenolic fluorophores or related chemical probes, as well as to amine-based dyes via carbamate linkers.

We initiated this study by preparing a general reagent for caging nucleophilic fluorophores via a protected homoallylamine with a $\beta$-leaving group. In a first working example, aminoallylation of 4-hydroxybutanone, 1, afforded aminoalcohol 2. Subsequent diazotransfer using Goddard-Borger's method $^{49}$ and tosylation afforded the key caging group 3 . We explored the caging properties of 3 by appending it to a known fluorescent scaffold, 2-methyl-4-methoxy-Tokyo Green (TG), 4. (Figure 1 ). ${ }^{44}$ This derivative has been utilized previously as a platform for reactivity-based bioimaging purposes through masking of its free phenolic group to limit conjugation through the xanthenone portion of the dye. ${ }^{50-55}$ Accordingly, Oalkylation of the fluorophore with $\mathrm{Cs}_{2} \mathrm{CO}_{3}$ and 3, followed by azide reduction using a tin(II) chloride/thiophenol mixture, ${ }^{56}$ yielded weakly fluorescent, caged TG 6 . Upon treatment with FA in aqueous PBS buffer at physiological $\mathrm{pH}$, the anion of 4 is released, resulting in a ca. 10 -fold fluorescence increase in response to $100 \mu \mathrm{M}$ FA within $2 \mathrm{~h}$ (Figure $1 \mathrm{~b}$ ). Moreover, the probe also displayed selectivity for FA over other relevant RCS and biological analytes (Figure 1c). Thus, this initial design of a self-immolative 2-aza-Cope reactivity trigger shows a promising approach to convert a phenol-containing fluorophore into a selective FA-responsive fluorescent indicator.

Structure-Activity Studies to Optimize the FA Responses of the Aza-Cope Reaction Trigger. The initial probe 6 established the viability of the aza-Cope reactivity trigger to selectively react with FA to induce a fluorescence response, but the relatively slow conversion of $\mathbf{6}$ into the uncaged fluorophore presaged potential limitations for its utility in live-cell imaging studies of FA biology. As such, we next explored several synthetic iterations of the trigger structure with the aim of improving aza-Cope reactivity to increase 
a)

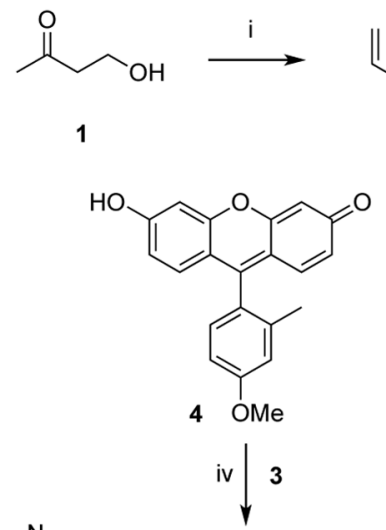

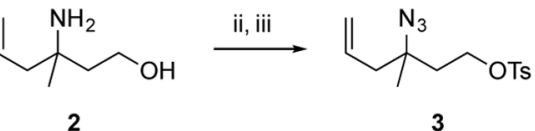

2

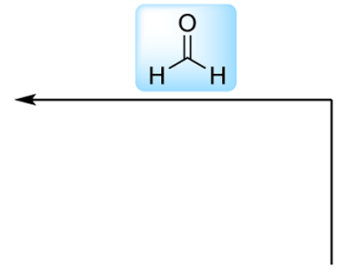

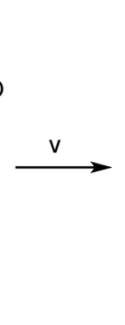

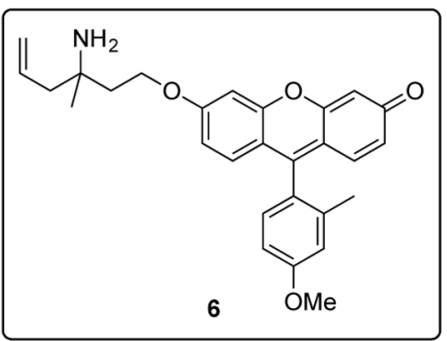

b)

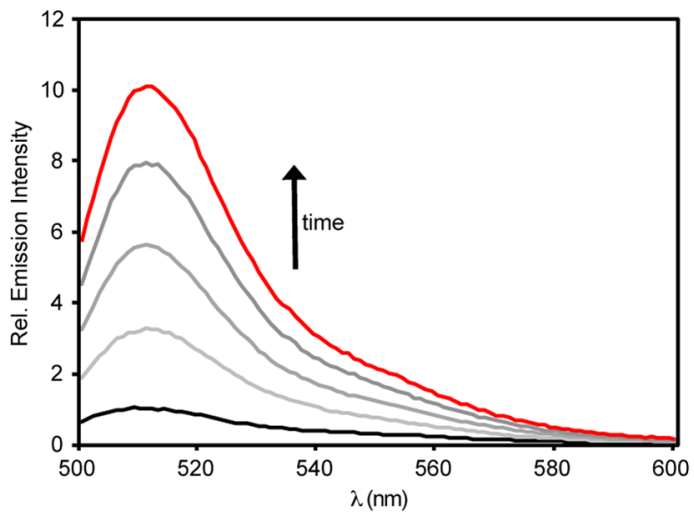

c)

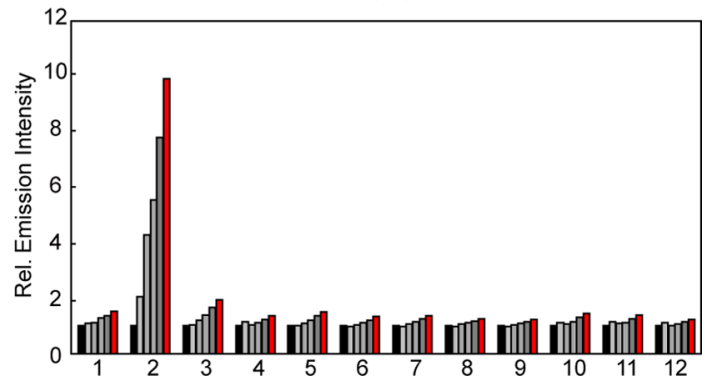

Figure 1. (a) Reagents and conditions: (i) $\mathrm{NH}_{3}, \mathrm{MeOH}, 0{ }^{\circ} \mathrm{C}$ to $\mathrm{rt}, 30 \mathrm{~min}$, then allyl pinacol boronate, rt, $24 \mathrm{~h}, 69 \%$; (ii) diazo transfer reagent, $\mathrm{CuSO}_{4} \cdot 5 \mathrm{H}_{2} \mathrm{O}, \mathrm{K}_{2} \mathrm{CO}_{3}, \mathrm{MeOH}$, rt, 20 h; (iii) TsCl, Et ${ }_{3} \mathrm{~N}, \mathrm{DMAP}, \mathrm{CH}_{2} \mathrm{Cl}_{2}, \mathrm{rt}, 16 \mathrm{~h}, 27 \%$ (2 steps); (iv) 3, $\mathrm{Cs}_{2} \mathrm{CO}_{3}, \mathrm{DMF}^{\circ}, 40{ }^{\circ} \mathrm{C}, 20 \mathrm{~h}, 62 \%$; (v) $\mathrm{SnCl}_{2}, \mathrm{PhSH}, \mathrm{Et} 3 \mathrm{~N}, \mathrm{MeCN}, \mathrm{rt}, 12 \mathrm{~h}, 91 \%$. (b) Fluorescence response and selectivity of $10 \mu \mathrm{M}$ probe 6 to $100 \mu \mathrm{M}$ FA. Data was acquired in $20 \mathrm{mM}$ PBS ( $\mathrm{pH} 7.4)$ at $37^{\circ} \mathrm{C}$. Emission was collected between $500-600 \mathrm{~nm}\left(\lambda_{\mathrm{ex}}=488 \mathrm{~nm}\right)$. Lines represent time points taken at 0 (black), 30 (light gray), 60 (gray), 90 (dark gray), and $120 \mathrm{~min}$ (red) after addition of $100 \mu \mathrm{M}$ FA. (c) Fluorescence response of $10 \mu \mathrm{M}$ probe 6 to RCS or relevant biological analyte. Data was acquired in $20 \mathrm{mM}$ PBS (pH 7.4) at $37^{\circ} \mathrm{C}$. Bars represent relative emission intensity responses to $100 \mu \mathrm{M}$ analyte after treatment for at 0 (black), 30 (light gray), 60 (gray), 90 (dark gray), and $120 \mathrm{~min}$ (red). Analytes were prepared as stated in the Selectivity Tests section of the SI. Legend: (1) PBS, (2) FA, (3) acetaldehyde, (4) acrolein, (5) glucose (1 mM), (6) $\mathrm{H}_{2} \mathrm{O}_{2},(7)$ methylglyoxal, (8) dehydroascorbate (9) pyruvate, (10) glucosone, (11) oxaloacetate, (12) 4-hydroxynonenal.

Scheme 2. Structural Variation of the Trigger at the 2 Position $^{a}$
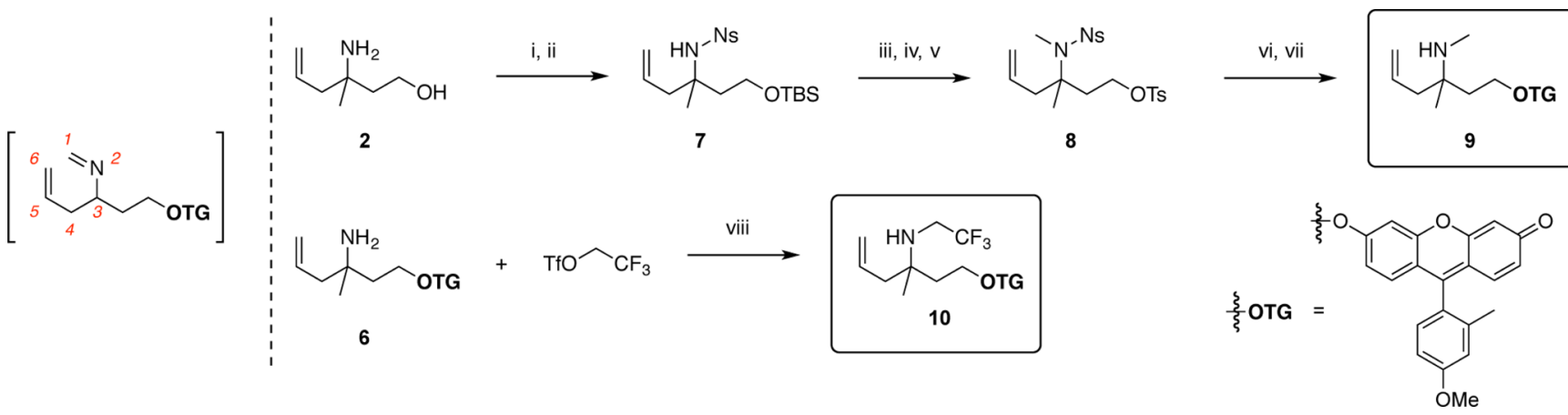

${ }^{a}$ Reagents and conditions: (i) TBSCl, imidazole, $\mathrm{CH}_{2} \mathrm{Cl}_{2}$, rt; (ii) 4-nitrotoluenesulfonyl chloride, $\mathrm{Et}{ }_{3} \mathrm{~N}, \mathrm{DMAP}, \mathrm{CH}_{2} \mathrm{Cl}_{2}, 0{ }^{\circ} \mathrm{C}$ to rt, $73 \%(3$ steps from 1); (iii) MeI, $\mathrm{K}_{2} \mathrm{CO}_{3}$, DMF, rt; (iv) TBAF, THF, rt, 95\% (2 steps); (v) TsCl, $\mathrm{Et}_{3} \mathrm{~N}, \mathrm{DMAP}, \mathrm{CH}_{2} \mathrm{Cl}_{2}, \mathrm{rt}, 89 \%$; (vi) 4, $\mathrm{Cs}_{2} \mathrm{CO}_{3}, \mathrm{DMF}^{\circ}, 50{ }^{\circ} \mathrm{C}$, 30\%; (vii) $\mathrm{PhSH}, \mathrm{K}_{2} \mathrm{CO}_{3}, \mathrm{MeCN}, 50{ }^{\circ} \mathrm{C}, 42 \%$; (viii) $\mathrm{K}_{2} \mathrm{CO}_{3}, \mathrm{MeCN}, \mathrm{DMF}, \mathrm{rt}, 20 \mathrm{~h}, 14 \%$.

fluorophore signal-to-noise responses. In particular, we targeted systematic modifications to the core trigger structure at the 2,3 , and 4 positions and installed these respective triggers onto the parent TG scaffold (Scheme 2).

Scheme 2 outlines the synthesis of probes 9 and 10, which are modified at the 2 position. The direct monoalkylation of 6 proved surprisingly challenging. An alternative approach used silyl protection and $N$-nosylation of 2 to yield sulfonamide 7 , which can be methylated readily. Conversion of the silyl ether to the tosylate afforded key linker 8. It is noted that judicious choice of protecting group strategies is critical, as attempts to prepare analogues of $\mathbf{8}$ containing a secondary carbamate or nosylate resulted in rapid intramolecular cyclizations. Conjugation of TG with $\mathbf{8}$ followed by nosyl group removal with thiophenol provided $\mathrm{N}$-methylated probe 9. An $\mathrm{N}$-trifluoroethylated analogue, 10, could be directly formed through alkylation of 6 with the corresponding triflate.

Probe 14, which possesses a hydrogen at the 3-position in place of the parent methyl group, was synthesized starting from commercially available homoallylamino acid 11. Reduction of the acid and Boc deprotection furnished aminoalcohol 12, which was then converted to azido tosylate 13. Conjugation to the TG fluorophore and azide reduction provided sterically unencumbered variant 14 . An alternate trigger modified at the 
Scheme 3. Structural Variation of the Trigger at the 3 Position $^{a}$<smiles>O=C(O)CC1CC=CCC1</smiles>

11<smiles>O=C(CCO)c1ccccc1</smiles><smiles>C=CCC(N)CCO</smiles>

12<smiles>C=CC(N)(CC[O-])c1ccccc1</smiles>
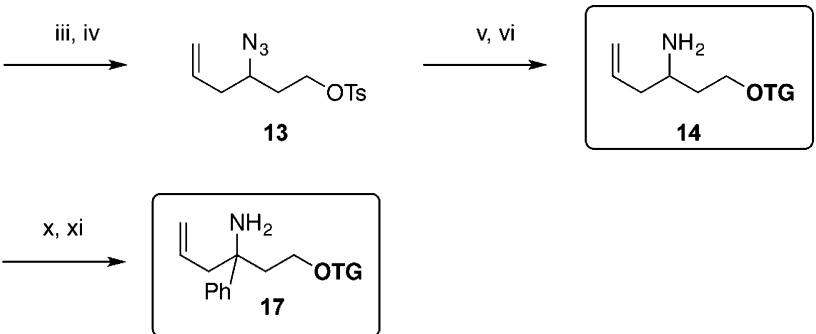

${ }^{a}$ Reagents and conditions: (i) ethyl chloroformate, $\mathrm{Et}_{3} \mathrm{~N}, \mathrm{THF}, 0{ }^{\circ} \mathrm{C}, 30 \mathrm{~min}$, then $\mathrm{NaBH}_{4}, \mathrm{THF}, \mathrm{H}_{2} \mathrm{O}, \mathrm{rt}, 2 \mathrm{~h}, 72 \%$; (ii) $\mathrm{HCl}, \mathrm{Et}_{2} \mathrm{O}, \mathrm{MeOH}^{\circ} 0{ }^{\circ} \mathrm{C}$ to rt, $3 \mathrm{~h}$; (iii) diazo transfer reagent, $\mathrm{CuSO}_{4} \cdot 5 \mathrm{H}_{2} \mathrm{O}, \mathrm{K}_{2} \mathrm{CO}_{3}, \mathrm{MeOH}$, rt, $14 \mathrm{~h}$; (iv) TsCl, Et ${ }_{3} \mathrm{~N}, \mathrm{DMAP}_{2} \mathrm{CH}_{2} \mathrm{Cl}_{2}, \mathrm{rt}, 24 \mathrm{~h}, 53 \%$ (3 steps); (v) 4, Cs $\mathrm{CO}_{3}$, DMF, $40{ }^{\circ} \mathrm{C}, 20 \mathrm{~h}, 58 \%$; (vi) $\mathrm{SnCl}_{2}, \mathrm{PhSH}_{2} \mathrm{Et}_{3} \mathrm{~N}, \mathrm{MeCN}$, rt, $2.5 \mathrm{~h}, 33 \%$; (vii) $\mathrm{NH}_{3}, \mathrm{MeOH}$, then allyl pinacol boronate; (viii) diazo transfer reagent, $\mathrm{CuSO}_{4} \cdot 5 \mathrm{H}_{2} \mathrm{O}, \mathrm{K}_{2} \mathrm{CO}_{3}, \mathrm{MeOH}, \mathrm{rt}, 78 \%$ (2 steps); (ix) TsCl, $\mathrm{Et}_{3} \mathrm{~N}, \mathrm{DMAP}, \mathrm{CH}_{2} \mathrm{Cl}_{2}$, rt, quantitative; (x) 4, $\mathrm{Cs}_{2} \mathrm{CO}_{3}, \mathrm{DMF}^{\circ}, 45{ }^{\circ} \mathrm{C}, 33 \%$; (xi) $\mathrm{SnCl}$, $\mathrm{PhSH}, \mathrm{Et}_{3} \mathrm{~N}, \mathrm{MeCN}, \mathrm{rt}, 74 \%$.

Scheme 4. Structural Variation of the Trigger at the 4 Position $^{a}$

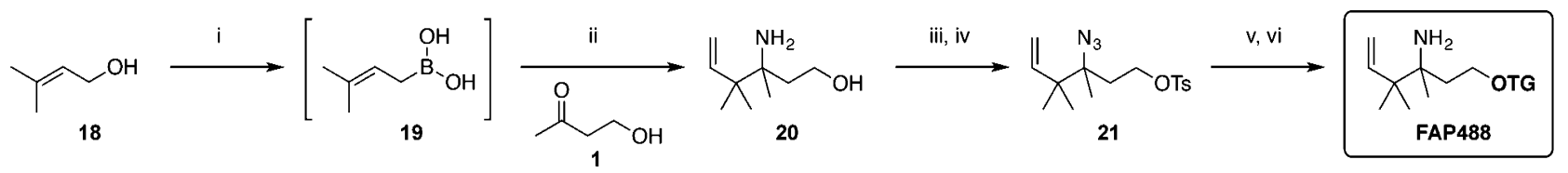

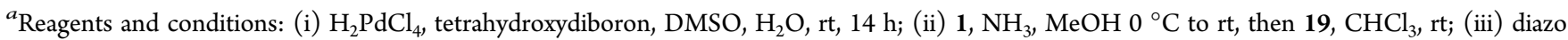
transfer reagent, $\mathrm{CuSO}_{4} \cdot 5 \mathrm{H}_{2} \mathrm{O}, \mathrm{K}_{2} \mathrm{CO}_{3}, \mathrm{MeOH}$, rt; (iv) TsCl, $\mathrm{Et}_{3} \mathrm{~N}, \mathrm{DMAP}, \mathrm{CH}_{2} \mathrm{Cl}_{2}, \mathrm{rt}$; (v) $4, \mathrm{Cs}_{2} \mathrm{CO}_{3}, \mathrm{DMF}, 40^{\circ} \mathrm{C}, 20 \mathrm{~h}$; (vi) SnCl, $\mathrm{PhSH}^{\mathrm{E}} \mathrm{Et}_{3} \mathrm{~N}$, $\mathrm{MeCN}, \mathrm{rt}, 18 \mathrm{~h}, 11 \%$ (2 steps).

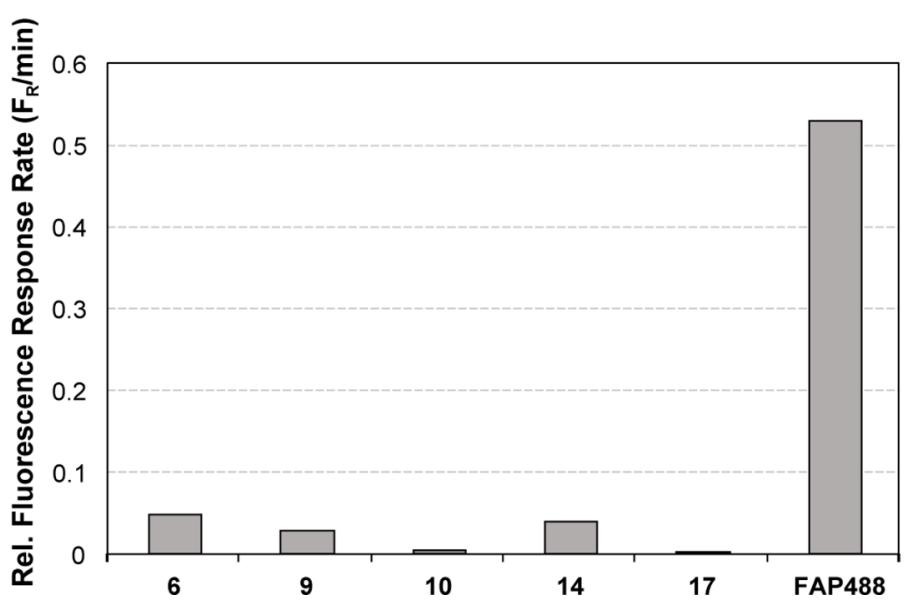<smiles>C=CCC(C)(N)CCO[Na]</smiles>

6<smiles>C=CCC(C)(CCO[O+])NC</smiles>

9<smiles>C=CCC(C)(CCOc1ccccc1)NCC(F)(F)F</smiles>

10<smiles>C=CCC(N)CCOCCO</smiles><smiles>C=CC(N)(CCO[GeH3])c1ccccc1</smiles>

17<smiles>C=CC(C)(C)C(C)(N)CC[O-]</smiles>

FAP488

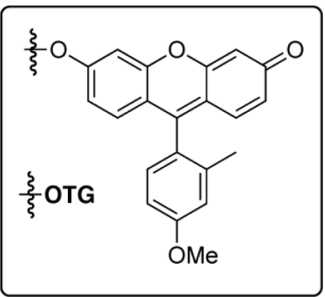

Figure 2. Relative fluorescence response rates of trigger structures appended to TG. Fluorescence response of $10 \mu \mathrm{M}$ probe to $1 \mathrm{mM}$ FA. Data was acquired in $20 \mathrm{mM}$ PBS ( $\mathrm{pH} 7.4)$ at $37{ }^{\circ} \mathrm{C}$. Emission was collected between $500-600 \mathrm{~nm}\left(\lambda_{\mathrm{ex}}=488 \mathrm{~nm}\right)$. Relative fluorescence response rate indicates the linear increase in fluorescence $/ \mathrm{min}$ at $\lambda_{\mathrm{em}}(518 \mathrm{~nm})$. Rate was determined by measuring a linear slope of the fluorescence intensity per min before saturation kinetics were observed (Figure S1-S6).

3-position was constructed beginning with aminoalkylation of ketone 15. The intermediate aminoalcohol was converted to the azide through diazo transfer and then transformed via tosylation to form 16. Fluorophore alkylation and azide reduction then produced caged TG 17, which contains a phenyl group at the 3-position (Scheme 3).

Recent work by Szabó on the addition of sterically hindered allyl boronic acids to ketones ${ }^{57}$ provided a synthetic route for the installation of alkyl groups at the 4-position of the aza-Cope trigger. In particular, key aminoalcohol intermediate 20, containing gem-dimethyl substitution at the 4-position, was synthesized by treating the imine of $\mathbf{1}$ with prenyl boronic acid 19 formed in situ. The resulting aminoalcohol was similarly converted to azido tosylate 21. Alkylation and azide reduction yielded caged TG, herein named Formaldehyde Probe 488
(FAP488, Scheme 4) corresponding to its excitation maximum at $488 \mathrm{~nm}$.

Effects of Trigger Modification on FA Probe Sensitivity and Signal-to-Noise Responses. With this family of TG derivatives caged with aza-Cope reactivity triggers modified at the 2, 3, and 4 positions in hand, we compared their relative responses to FA in vitro. Relative probe sensitivity was determined based on the fluorescence response rate of the probe relative to 6 . Specifically, compounds $9,10,14,17$, and FAP488 were treated with $1 \mathrm{mM}$ FA in PBS buffer, and the change in fluorescence was monitored over time (Figure 2). We observed that modifications at the 2 position $(9,10)$ resulted in a poorer fluorescence response relative to parent probe 6 . We speculate that this decrease in signal-to-noise sensitivity may potentially result from increased steric encumbrance. Addition- 
Scheme 5. Synthesis of a Series of FA-Responsive Fluorescent Probes
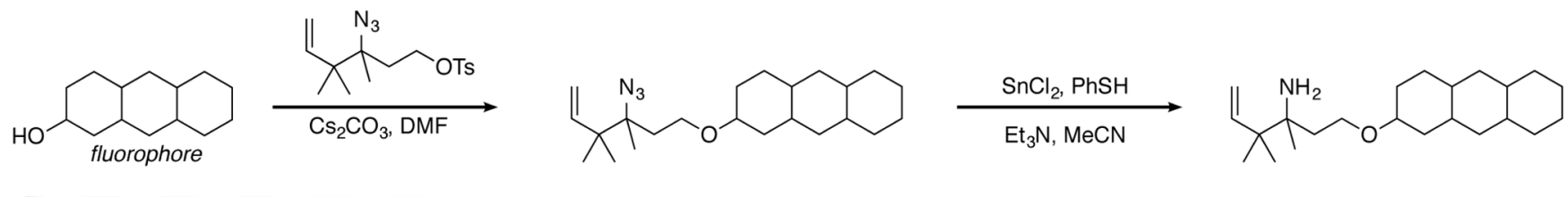

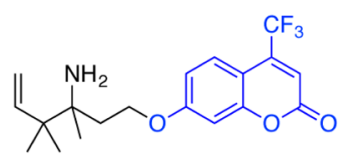

FAP385

$\lambda_{\mathrm{ex}}=385 \mathrm{~nm} / \lambda_{\mathrm{em}}=498 \mathrm{~nm}$

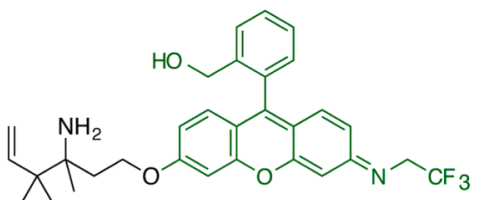

FAP498

$\lambda_{\text {ex }}=498 \mathrm{~nm} / \lambda_{\text {em }}=515 \mathrm{~nm}$

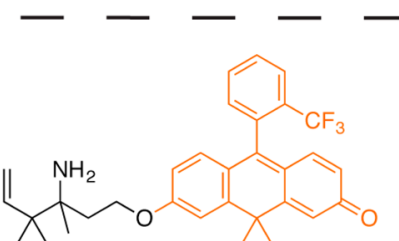

FAP555

$\lambda_{\text {ex }}=555 \mathrm{~nm} / \lambda_{\text {em }}=572 \mathrm{~nm}$

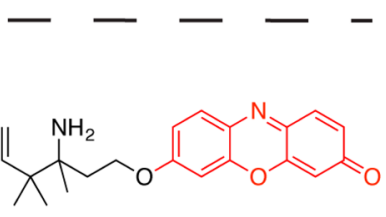

FAP573

$\lambda_{\text {ex }}=573 \mathrm{~nm} / \lambda_{\text {em }}=585 \mathrm{~nm}$ ally, the minimal response of $\mathbf{1 0}$ to FA may also be rationalized through decreased nitrogen nucleophilicity due to the inductive effects of the trifluoroethyl group, resulting in a slower initial condensation reaction with FA. Probes modified at the 3 position produced similar (14) or reduced (17) fluorescent responses relative to initial probe 6 . In contrast, FAP488, which possesses a gem-dimethyl group at the 4-position, displays greatly enhanced sensitivity to FA, showing an order of magnitude improvement in relative fluorescence response rate compared to the parent trigger that lacks these methyl substituents (Figure 2). We attribute this result to the gemdisubstitution effect, thereby increasing the rate of the aza-Cope reaction. ${ }^{58}$

In particular, substitution at the 4-position is anticipated to favor the rearranged imine en route to fluorophore uncaging. The ca. 10-fold fluorescence enhancement displayed by FAP488 relative to parent probe 6 presages that probes derived from aza-Cope trigger piece $\mathbf{2 1}$ would yield fluorescent FA indicators with greater signal-to-noise responses and FA sensitivity. As such, this improved aza-Cope trigger provides a starting point for further fluorescent probe development.

Developing a Series of Fluorescent FA probes with Varying Excitation/Emission Profiles with a General AzaCope Trigger. With these results in hand, we then used the gem-dimethyl aza-Cope trigger as a general caging group to create a series of homologous FA probes with fluorescence excitation and emission profiles that span the UV through visible spectral regions (Scheme 5). The naming convention for these FA indicators follows as Formaldehyde Probe (FAP) with a number corresponding to its maximal excitation wavelength. For example, we utilized a trifluoromethyl-substituted coumarin with an excitation wavelength of $385 \mathrm{~nm}$ to produce FAP385 as a blue-emitting probe. FAP498 is derived from a green-emitting trifluoroethyl rhodol scaffold that exhibits an excitation wavelength of $498 \mathrm{~nm}$. A carbofluorescein scaffold with the carboxylic acid substituted for a trifluoromethyl group was prepared for an orange-emitting FAP555 with an excitation wavelength of 555 nm. ${ }^{59}$ Finally, the red-emitting FAP573 is based on a resorufin scaffold with a corresponding excitation wavelength of $573 \mathrm{~nm}$.

Notably, all four of these probes, along with FAP488, feature distinctly different fluorescent scaffolds with varying excitation/ emission profiles but can all be synthesized using the same trigger conjugation strategy. Briefly, treatment of the fluorophore with $\mathrm{Cs}_{2} \mathrm{CO}_{3}$ and tosylate 21 allows for the conjugation of the azide-trigger to the parent dye. Reduction of the azide through a tin(II) chloride/thiophenol mixture gives the homoallylamine-trigger conjugated to the fluorophore.

Spectroscopic Responses to FA and FA Selectivity. We next evaluated the fluorescence responses of the FAP series to FA in aqueous solution buffered to physiological $\mathrm{pH}$ (Figure 3). FAP385 is initially weakly fluorescent $\left(\phi_{\mathrm{fl}}=0.11, \varepsilon_{385}=1750\right.$ $\mathrm{M}^{-1} \mathrm{~cm}^{-1}$ ) and exhibits a ca. 4.5-fold fluorescence turn-on response to $100 \mu \mathrm{M}$ FA after $2 \mathrm{~h}$. FAP498 $\left(\phi_{\mathrm{fl}}=0.23, \varepsilon_{480}=\right.$ $1818 \mathrm{M}^{-1} \mathrm{~cm}^{-1}$ ) shows only a ca. 2.2 -fold response to $100 \mu \mathrm{M}$ FA after $2 \mathrm{~h}$ due to the higher initial fluorescent background signal, which is likely a result of the more favorable equilibrium of the open-form alcohol over the closed-form lactone in aqueous solution at near neutral $\mathrm{pH}$. FAP555 $\left(\phi_{\mathrm{fl}}=0.50, \varepsilon_{573}=\right.$ $\left.12175 \mathrm{M}^{-1} \mathrm{~cm}^{-1}\right)$ displays a large bathochromic shift upon elimination of the trigger, leading to a ca. 10-fold increase in fluorescence response to FA after $2 \mathrm{~h}$. Similar to FAP385, FAP573 displays weak initial fluorescence $\left(\phi_{\mathrm{fl}}=0.18, \varepsilon_{573}=\right.$ $\left.1369 \mathrm{M}^{-1} \mathrm{~cm}^{-1}\right)$ and gives a ca. 4-fold increase in fluorescence response to $\mathrm{FA}$ after $2 \mathrm{~h}$. At $10 \mu \mathrm{M}$ probe after $2 \mathrm{~h}$ incubation, all probes display a $10 \mu \mathrm{M}$ limit of detection for FA (Figure S7). The pseudo first order kinetic plots of FAP498, FAP555, and FAP573 all display similar rate constants of $k=7 \times 10^{-4}$ $\mathrm{s}^{-1}$, which can be converted into bimolecular rate constants of $k$ $=0.14(1) \mathrm{M}^{-1} \mathrm{~s}^{-1}$ by taking into account the concentration of FA $(5 \mathrm{mM})$ used in high excess for these experiments (Figure S8).

The data show that this gem-dimethyl aza-Cope trigger allows for the rational and general functionalization of a wide variety of fluorophores for FA detection by separating the dye scaffold from the FA-reactive cage. As expected from the demonstrated FA specificity of the aza-Cope reaction trigger for FA, FAP385, FAP498, FAP555, and FAP573 all exhibit high selectivity for FA over a panel of biologically relevant RCS such as methylglyoxal, 4-hydroxynonenal, and acetaldehyde. Moreover, these aldehydes do not interfere with the turn-on response of these reagents to FA (Figure S9). The probes also do not respond to addition of reagents that induce higher levels of oxidizing $\left(\mathrm{H}_{2} \mathrm{O}_{2}\right)$ and reducing (glutathione) equivalents in the cell. ${ }^{60}$ Taken together, the data establish that this 2-aza-Cope reactivity trigger can be generally applied to develop probes with a selective response to $\mathrm{FA}$ with varying excitation and emission colors.

Application of FAP Reagents to Turn-on Fluorescence Detection of Changes in FA Levels in Living Cells. After confirming all four FAP probes are responsive and selective for FA in aqueous buffer, we next assessed their capability for detecting changes in FA levels in living cells. Incubation of 

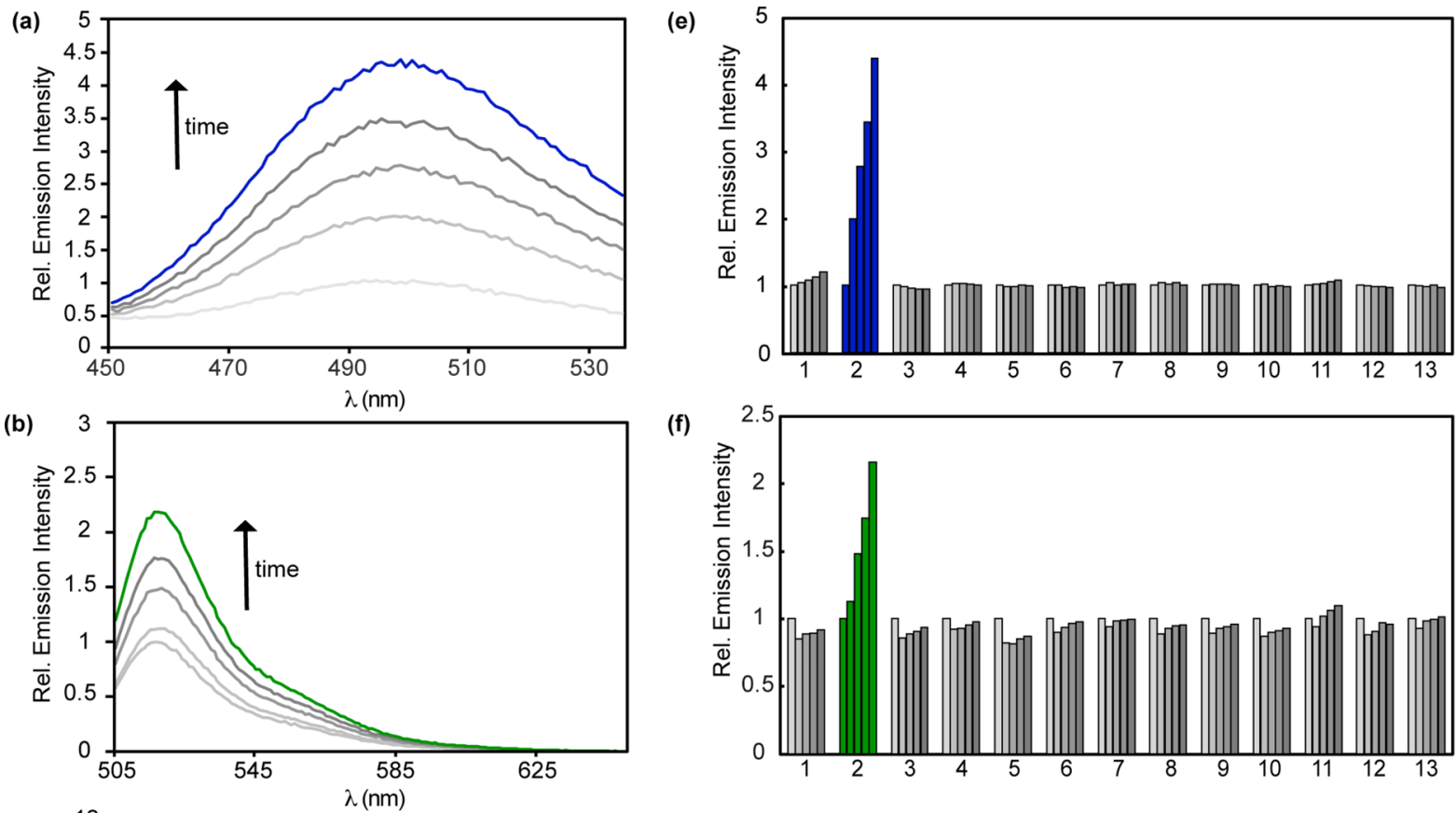

(f)
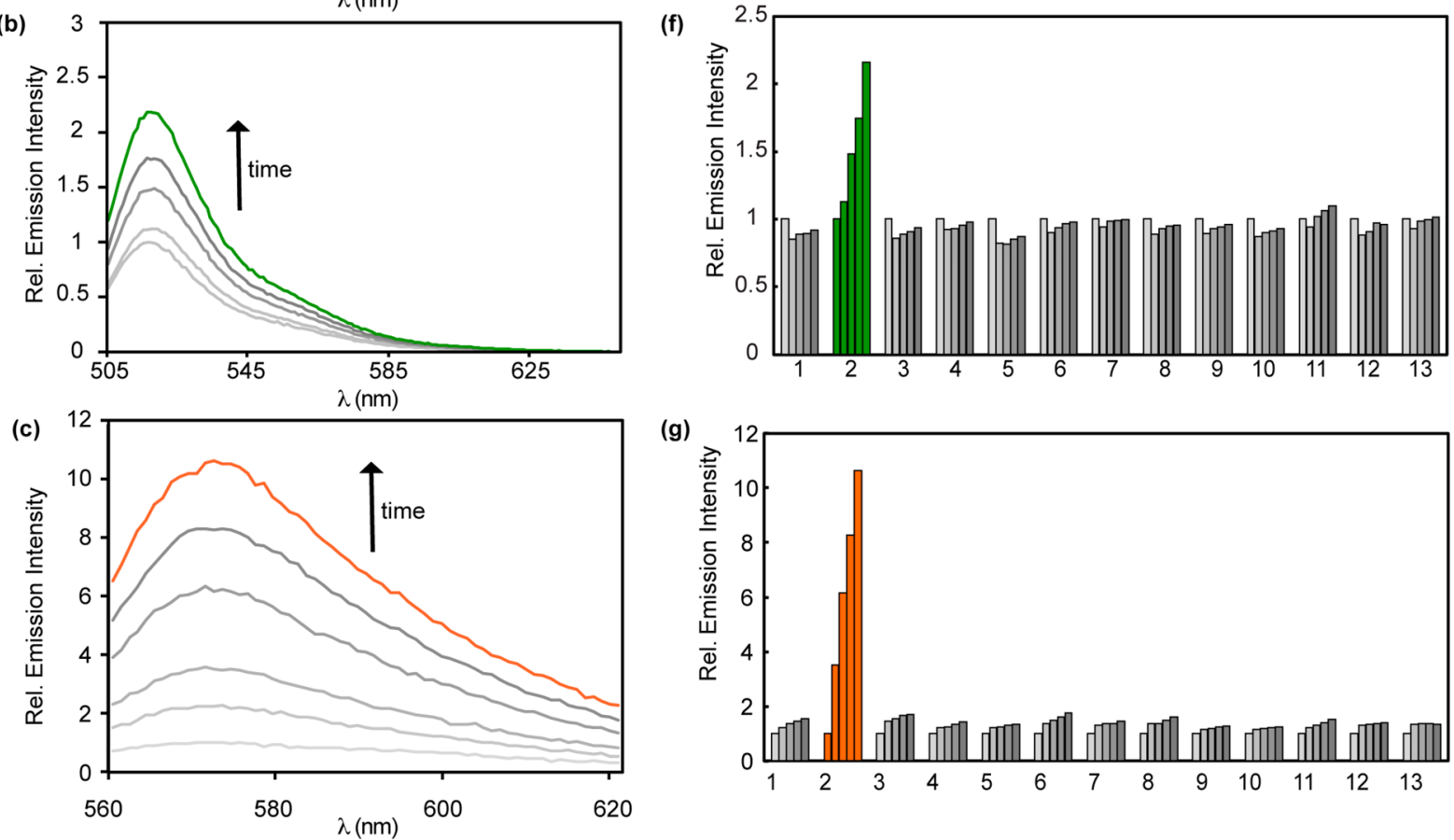

(g)
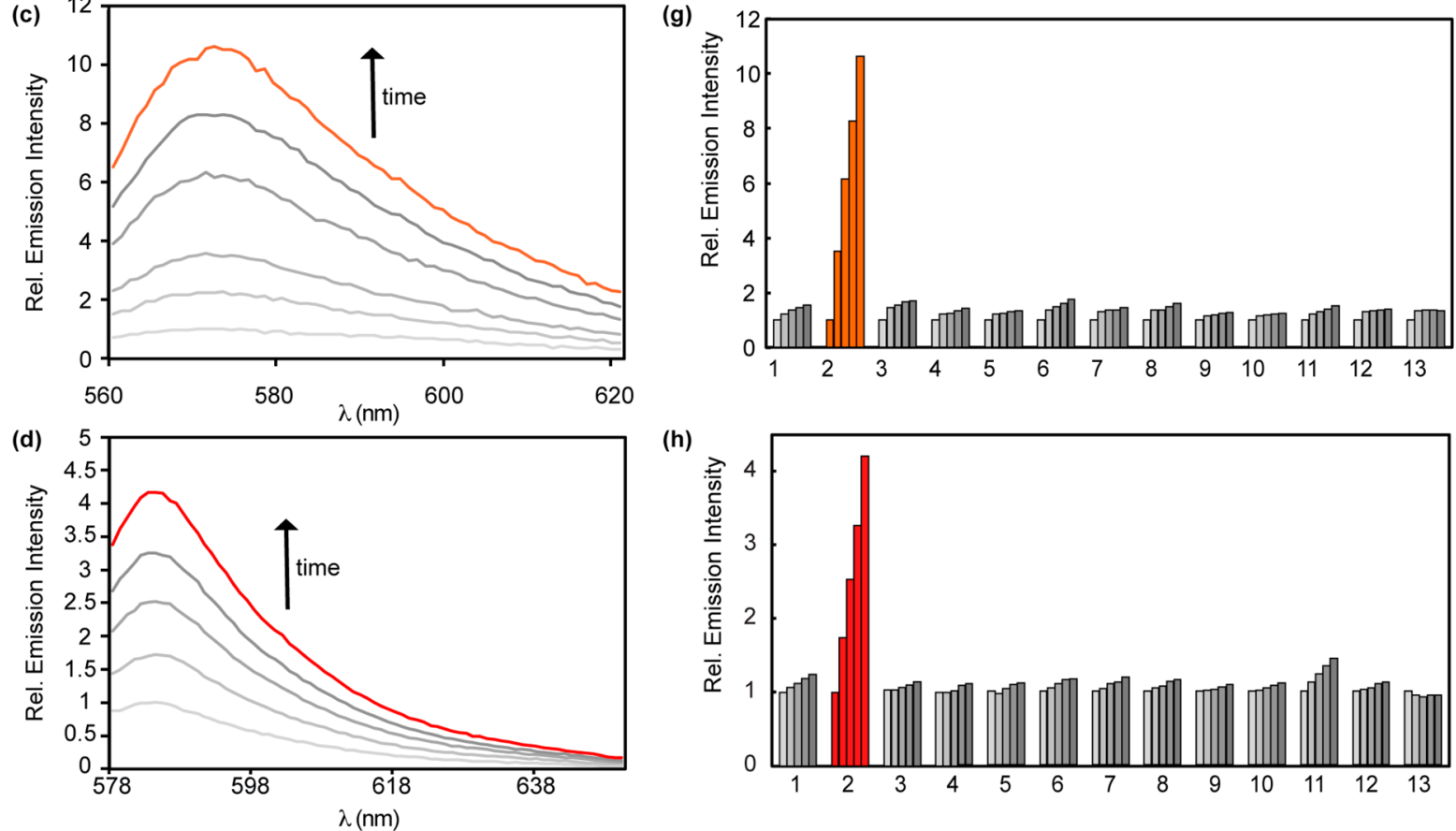

(h)

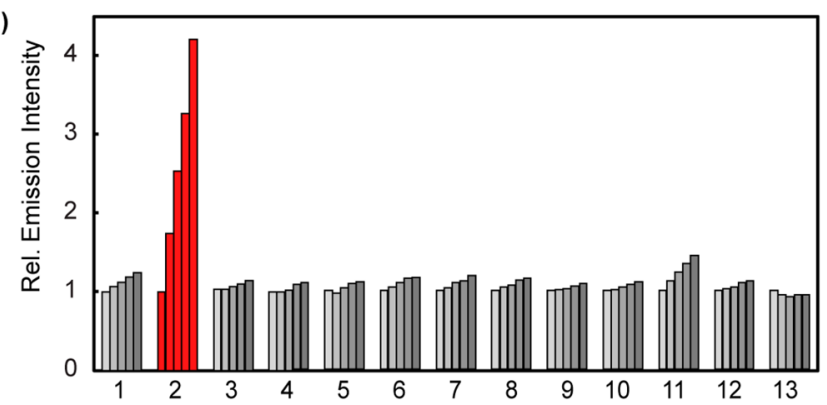

Figure 3. Fluorescence responses and selectivities of FA probes. (a-c) Fluorescence responses of $10 \mu \mathrm{M}$ (a) FAP385, (b) FAP498, (c) FAP555, or (d) FAP573 to $100 \mu \mathrm{M}$ FA. Data were acquired in $20 \mathrm{mM}$ PBS (pH 7.4) at $37^{\circ} \mathrm{C}$. Emission was collected between (a) $450-535 \mathrm{~nm}\left(\lambda_{\text {ex }}=385\right.$ $\mathrm{nm})$, (b) $505-645 \mathrm{~nm}\left(\lambda_{\mathrm{ex}}=498 \mathrm{~nm}\right)$, (c) $560-625 \mathrm{~nm}\left(\lambda_{\mathrm{ex}}=555 \mathrm{~nm}\right)$ or (d) $578-650 \mathrm{~nm}\left(\lambda_{\mathrm{ex}}=573 \mathrm{~nm}\right)$. Lines represent time points taken at 0 (lightest gray), 30 (light gray), 60 (gray), 90 (dark gray), and $120 \mathrm{~min}$ (colored) after addition of $100 \mu \mathrm{M} \mathrm{FA}$. (e-h) Fluorescence responses of 10 $\mu \mathrm{M}$ probe to RCS or relevant biological analyte. Bars represent emission intensity responses to $100 \mu \mathrm{M}$ analyte unless otherwise stated for 0 (lightest gray), 30 (light gray), 60 (gray), 90 (dark gray), and 120 (darkest gray) min, except FA, which is shown in colored bars. Analytes were prepared as stated in the Selectivity Tests section of the SI. Legend: (1) PBS, (2) FA, (3) acetaldehyde, (4) glucose (1 mM), (5) 4-hydroxynonenal, (6) dehydroascorbate, (7) glucosone, (8) pyruvate, (9) oxaloacetate, (10) acrolein, (11) methylglyoxal, $(12) \mathrm{H}_{2} \mathrm{O}_{2}$, (13) glutathione (5 mM).

HEK293T cells with $10 \mu \mathrm{M}$ FAP385 (Figure S10), $5 \mu \mathrm{M}$ FAP498 (Figure 4), $10 \mu \mathrm{M}$ FAP555 (Figure 5), or $10 \mu \mathrm{M}$ FAP573 (Figure 6) for $30 \mathrm{~min}$ at $37^{\circ} \mathrm{C}$ in BSS buffer, followed by a wash into fresh buffer to remove excess probe, allowed for initial probe staining of cells with low background. Exogenous additions of 200-1000 $\mu \mathrm{M}$ FA for 30 and 60 min resulted in a linear increase for green, orange, and red intracellular fluorescence for FAP498, FAP555, and FAP573, respectively, establishing the utility of these three indicators for live-cell FA imaging However, cells incubated with FAP385 display a background increase in the surrounding media over the course of the FA treatment, suggesting that the lower fluorescence response for live-cell imaging may be due to poor cellular retention of the probe or its fluorescent product (Figure S10). Flow cytometry experiments were performed to verify probe turn-on in cells (Figure S11-S13). In all cases, nuclear staining 

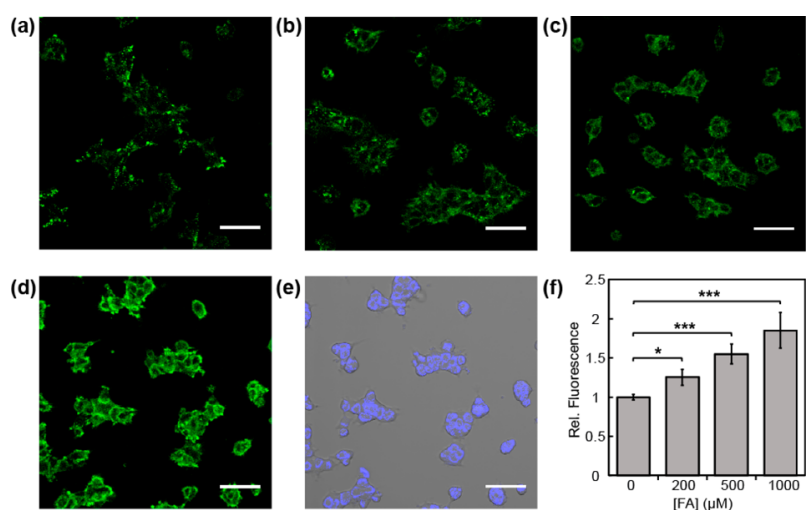

Figure 4. Confocal microscopy images of FAP498 in response to exogenous FA addition in HEK293T cells. Cells were treated with 5 $\mu \mathrm{M}$ FAP498 in BSS buffer for $30 \mathrm{~min}$, exchanged into fresh buffer, and then treated with (a) vehicle, (b) 200, (c) 500, or (d) $1000 \mu \mathrm{M}$ FA. Images were taken after $60 \mathrm{~min}$. (e) Bright field image of cells in (d) overlaid with $1 \mu \mathrm{M}$ Hoechst 33342. (f) Mean fluorescent intensities of cells in $(\mathrm{a}-\mathrm{d}) 60 \mathrm{~min}$ after addition of $\mathrm{FA}$ relative to mean fluorescence intensity before addition of vehicle or FA; error bars denote SEM $(n=3)$. $* P<5 \times 10^{-3}, * * * P<5 \times 10^{-5}$. Scale bar represents $50 \mu \mathrm{m}$ in all images.
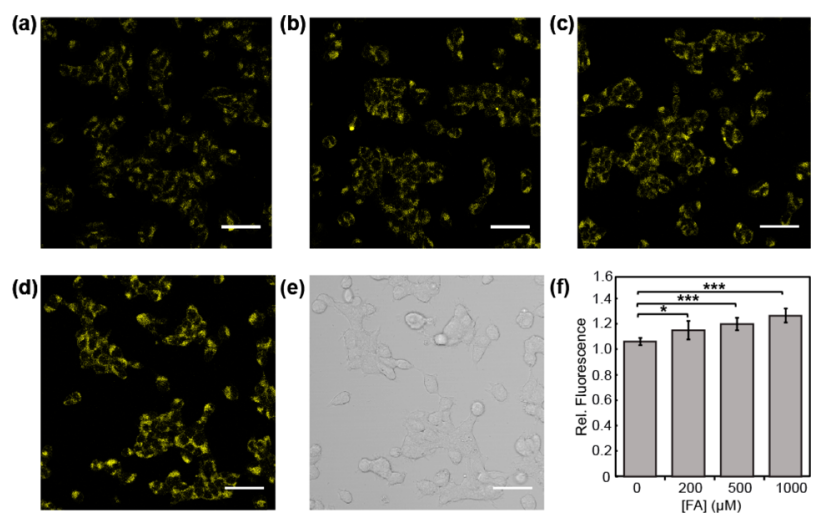

Figure 5. Confocal microscopy images of FAP555 in response to exogenous FA addition in HEK293T cells. Cells were treated with 10 $\mu \mathrm{M}$ FAP555 in BSS buffer for $30 \mathrm{~min}$, exchanged into fresh buffer, and then treated with (a) vehicle, (b) 200, (c) 500, or (d) $1000 \mu \mathrm{M}$ FA. Images were taken after $60 \mathrm{~min}$. (e) Bright field image of cells in (d). (f) Mean fluorescent intensities of cells in $(\mathrm{a}-\mathrm{d}) 60$ min after addition of FA relative to mean fluorescence intensity before addition of vehicle or FA; error bars denote SEM $(n=3)$. $* P<5 \times 10^{-3}, * * * P<5 \times$ $10^{-5}$. Scale bar represents $50 \mu \mathrm{m}$ in all images.

and/or flow cytometry experiments confirmed that the cells remain viable throughout the course of the experiment (Figure S14). For the case of FAP555, nuclear staining was not used due to the broad excitation of both the caged $\left(\lambda_{\mathrm{ex}}=420 \mathrm{~nm}\right)$ and uncaged probe overlapping with commonly available nuclear dyes.

While three probes are capable of detecting changes in intracellular FA levels with exogenously added FA, we observed that FAP498 and FAP555 exhibit a lower fluorescence turn-on response to FA compared to FAP573, which displays the best response to $\mathrm{FA}$ in this series owing to its relatively homogeneous staining and good cellular retention throughout the imaging experiments. These properties led us to utilize FAP573 in further experiments to study endogenous FA metabolism in living cells.
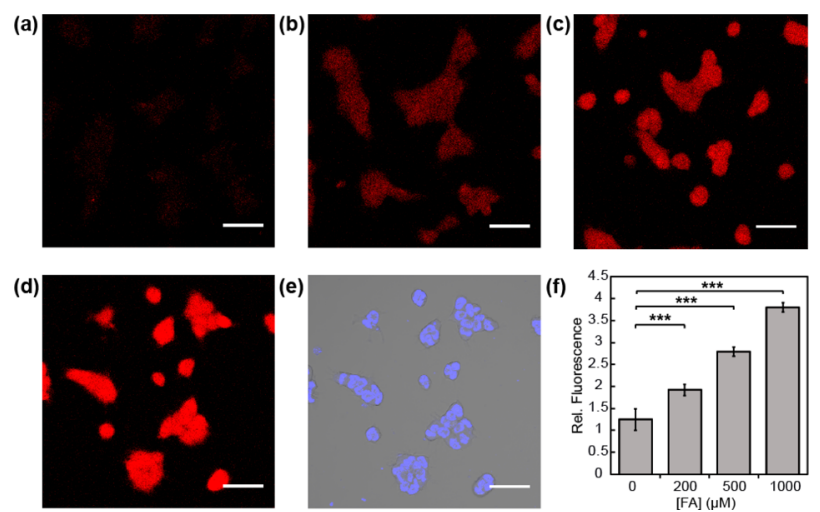

Figure 6. Confocal microscopy images of FAP573 in response to exogenous FA addition in HEK293T cells. Cells were treated with 10 $\mu$ M FAP573 in BSS buffer for $30 \mathrm{~min}$, exchanged into fresh buffer, and then treated with (a) vehicle, (b) 200, (c) 500, or (d) $1000 \mu \mathrm{M}$ FA. Images were taken after $60 \mathrm{~min}$. (e) Bright field image of cells in (d) overlaid with $1 \mu \mathrm{M}$ Hoechst 33342. (f) Mean fluorescent intensities of cells in $(\mathrm{a}-\mathrm{d}) 60 \mathrm{~min}$ after addition of FA relative to mean fluorescence intensity before addition of vehicle or FA; error bars denote SEM $(n=3)$. $* * * P<5 \times 10^{-5}$. Scale bar represents $50 \mu \mathrm{m}$ in all images.

FAP573 Enables Detection of FA Fluxes via ADH5 Metabolism. We next sought to establish the potential value of FAP573 for monitoring intracellular metabolism of FA to identify sources and targets of this RCS. In this context, alcohol dehydrogenase 5 (ADH5) is a major enzyme responsible for cellular FA metabolism, and the recent development of two ADH5 knockout (KO) cell lines, mouse endothelial fibroblasts $^{61}$ (MEF) and near-haploid cells (HAP1) (Figure S15), offers the possibility to directly evaluate whether FAP reagents can monitor potential changes in FA levels regulated by this enzyme in living cells. Along these lines, we reasoned that ADH5 KO cells would exhibit impaired FA clearance compared to wild-type (WT) counterparts. To test this hypothesis, WT and KO MEF (Figure S16) or KO HAP1 (Figure 7) cells were loaded with $10 \mu \mathrm{M}$ FAP573 in BSS buffer
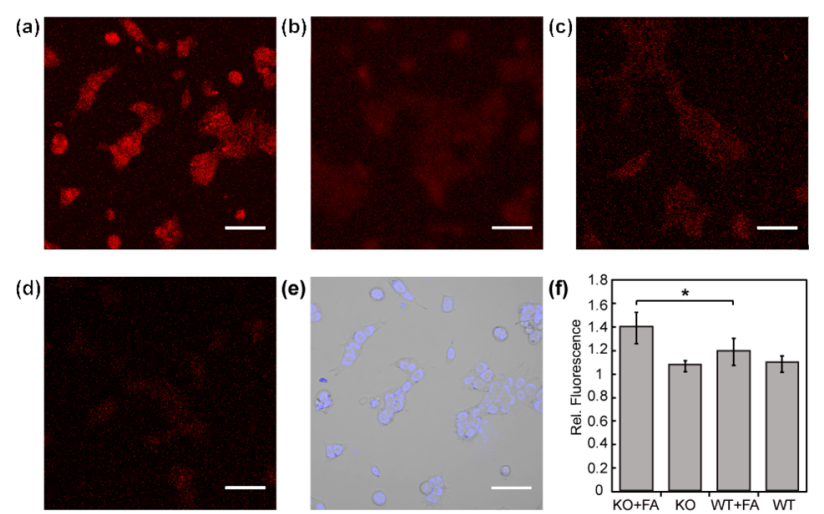

Figure 7. Confocal microscopy images of FAP573 in response to FA metabolism in ADH5 KO (a,b) or WT $(\mathrm{c}, \mathrm{d})$ HAP1 cells. Cells were treated with $10 \mu \mathrm{M}$ FAP573 for $30 \mathrm{~min}$, exchanged into fresh buffer, and then treated with vehicle $(\mathrm{b}, \mathrm{d})$ or $100 \mu \mathrm{M}$ FA $(\mathrm{a}, \mathrm{c})$. Images were taken after $60 \mathrm{~min}$. (e) Bright field image of (a) overlaid with $1 \mu \mathrm{M}$ Hoechst 33342. (f) Mean fluorescent intensities of cells in (a-d) 60 min after addition of FA relative to mean fluorescence intensity before addition of vehicle or FA; error bars denote SEM $(n=3) . * P<5 \times$ $10^{-3}$. Scale bar represents $50 \mu \mathrm{m}$ in all images. 
at $37^{\circ} \mathrm{C}$ for $30 \mathrm{~min}$. The cells were washed with fresh buffer to remove excess probe, and then incubated with 0 or $100 \mu \mathrm{M}$ FA for $60 \mathrm{~min}$. Nuclear staining and flow cytometry experiments confirm cell viability during the experiment (Figure S14). Interestingly, FAP573 showed patently higher fluorescence signals in both MEF KO and HAP1 KO cells compared to their WT congeners upon FA incubation by both confocal microscopy and flow cytometry (Figure S17), establishing that FA metabolism is impeded in the KO cells. Moreover, addition of a FA scavenger, $\mathrm{NaHSO}_{3}$, ${ }^{35}$ showed a lower level of fluorescence under the same conditions, confirming the fluorescence increase due to lower FA metabolism (Figure S18). Furthermore, FAP573 was able to show a higher level of fluorescence to basal levels of FA in KO cells compared to WT and $\mathrm{KO}$ cells with $\mathrm{NaHSO}_{3}$ by confocal microscopy and flow cytometry (Figure 8). Elimination of $\mathrm{ADH} 5$ results in a loss of (a)
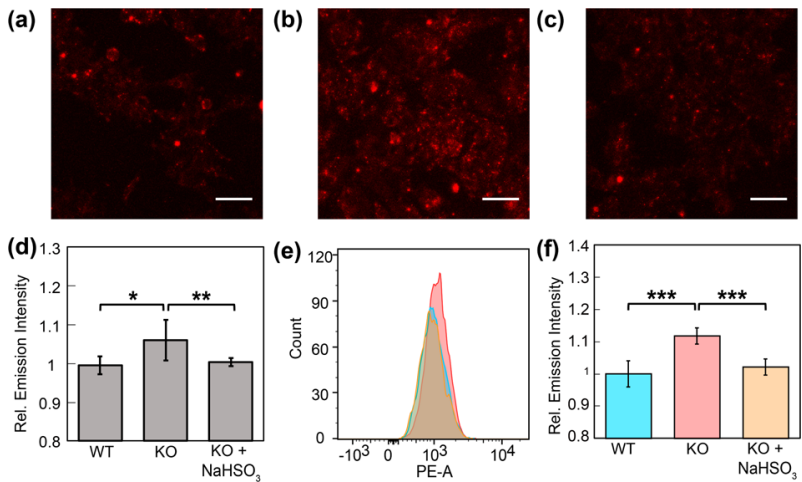

Figure 8. Confocal microscopy images $(\mathrm{a}-\mathrm{c}$ ) and flow cytometry histograms (e) of FAP573 in response to basal FA levels in (a) WT, (b) ADH5 KO, and (c) ADH5 KO HAP1 cells with $200 \mu \mathrm{M} \mathrm{NaHSO}_{3}$. (a,b) Cells were treated with $1 \mu \mathrm{M}$ FAP573 for $30 \mathrm{~min}$, then exchanged into fresh buffer. (c) Cells were treated with $200 \mu \mathrm{M}$ $\mathrm{NaHSO}_{3}$ for $30 \mathrm{~min}$, and then as in (a,b) keeping $200 \mu \mathrm{M} \mathrm{NaHSO}$ present in all buffers. Images were taken after $60 \mathrm{~min}$. (d) Mean fluorescent intensities of cells in $(a-c) 60$ min after addition of FAP573 to mean fluorescence intensity of cells in (a). (e) Representative flow cytometry experiment of $1 \mu \mathrm{M}$ FAP573 incubated in WT (blue), ADH5 KO (red) or $\mathrm{KO}$ cells with $\mathrm{NaHSO}_{3}$ (orange) for $1 \mathrm{~h}$. (f) Mean fluorescence intensity of median PE-A fluorescence relative to fluorescence intensity of median PE-A in the WT cells; error bars denote $\operatorname{SEM}(n=3)$. $* P<5 \times 10^{-3}, * * P<5 \times 10^{-4}$. *** $P<5 \times$ $10^{-5}$. Scale bar represents $50 \mu \mathrm{m}$ in all images.

a key FA metabolism pathway and excess buildup of this RCS, which has been shown to be a metabolic carcinogen and a hemoatopoietic stem cell genotoxin related to leukemia models. These data provide a unique example of a chemical tool that enables direct visualization of endogenous FA in living systems through fluorescence imaging with identification of a specific molecular source for its metabolism.

\section{CONCLUDING REMARKS}

We have presented the development of a general 2-aza-Cope reactivity trigger and its application to produce fluorescent probes for imaging FA in living cells. Rational, iterative optimization on a Tokyo Green platform affords a gemdimethyl derivative bearing a self-immolative $\beta$-elimination linker that can be installed onto any fluorescent dye scaffold that bears a phenol functionality. Notably, this relatively modest chemical change enables a ca. 10-fold increase in fluorescence turn-on response over the parent homoallylamine trigger. By separating the FA-reactive cage from the fluorophore backbone, FA responses can be tuned in a dye-independent manner to create a broad range of FA probes in a convergent fashion. We have applied this trigger to produce a set of fluorescent probes for FA detection with high and predictable selectivity and sensitivity for monitoring FA in solution and in cells with excitation and emission colors that span from blue to green to orange to red, either by flow cytometry and/or live-cell imaging. Resorufin-based FAP573 exhibits the best signal-tonoise response and most red-shifted excitation and emission profile enables identification of $\mathrm{ADH} 5$ as a key enzyme for endogenous metabolism of FA in living cells using ADH5 KO fibroblast and haploid cell models. Current efforts are underway to further expand the scope of this aza-Cope reactivity trigger for developing FA probes with expanded color palettes, cellular and subcellular targeting capabilities, and application to different chemical strategies for FA imaging and therapeutic applications. Because this trigger is potentially applicable to any alcohol or amine scaffold by a direct connection or through an additional self-immolative linkage, we envision the broader utility of this chemistry in elucidating new sources and targets of FA metabolism in biological pathways related to cell viability and disease state progression, akin to the boronate trigger that has proven useful for studying the chemical biology of hydrogen peroxide. $^{62,63}$ Of particular interest is identifying and elucidating the contributions of FA in biological stress mechanisms during carcinogenesis, asthma progression, and neurodegenerative disorders.

\section{EXPERIMENTAL DETAILS}

Synthetic Materials and Methods. Reactions utilizing air- or moisture-sensitive reagents were performed in oven- or flame-dried glassware under an atmosphere of dry $\mathrm{N}_{2}$. Reagents from commercial sources were used without further purification. 4-Hydroxynonenal solution was purchased from Cayman Chemical (Ann Arbor, MI); 2,2,2-trifluoroethyl trifluoromethanesulfonate was purchased from AK Scientific (Union City, CA); glucosone was purchased from Santa Cruz Biotech (Dallas, TX); thiophenol was purchased from Oakwood Chemical (Estill, SC); 3-((tert-butoxycarbonyl)amino)hex-5-enoic acid was purchased from ChemPep (Wellington, Fl); and all other reagents were purchased from Sigma-Aldrich (St. Louis, MO). 1-(Azidosulfonyl)-1H-imidazol-3-ium chloride (Goddard's diazo transfer reagent) was prepared according to published procedures. ${ }^{49}$ Prenylboronic acid solution was prepared through a slightly modified literature procedure. $^{64}$ 3,6-Bis ((tert-butyldimethylsilyl)oxy)-10,10-dimethylanthracen-9(10H)-one was prepared according to published procedures. $^{59}(Z)-9-(2-($ Hydroxymethyl $)$ phenyl)-3-((2,2,2-trifluoroethyl)imino)-3H-xanthen-6-ol was prepared according to published procedures. ${ }^{65}$ Silica gel P60 (SiliCycle) was used for all column chromatography purifications and SiliCycle 60 F254 silica gel (precoated sheets, $0.25 \mathrm{~mm}$ thick) was used for thin layer chromatography. ${ }^{1} \mathrm{H}$ NMR and ${ }^{13} \mathrm{C}$ NMR spectra were collected in $\mathrm{CDCl}_{3}$ or $\mathrm{CD}_{3} \mathrm{OD}$ (Cambridge Isotope Laboratories, Cambridge, MA) at $25{ }^{\circ} \mathrm{C}$ on Bruker AV-500 and AV-300 (used for ${ }^{1} \mathrm{H}$ NMR only), AVB-400, and AVQ-400 with ${ }^{13} \mathrm{C}$ operating frequencies of 101 $\mathrm{MHz}$ at the College of Chemistry NMR Facility at the University of California, Berkeley. Chemical shifts are reported in the standard $\delta$ notation of parts per million relative to residual solvent peak at 7.26 $\left(\mathrm{CDCl}_{3}\right)$ or $3.31\left(\mathrm{CD}_{3} \mathrm{OD}\right)$ for ${ }^{1} \mathrm{H}$ and $77.16\left(\mathrm{CDCl}_{3}\right)$ or 49.00 $\left(\mathrm{CD}_{3} \mathrm{OD}\right)$ for ${ }^{13} \mathrm{C}$ as an internal reference. Splitting patterns: br, broad; s, singlet; $\mathrm{d}$, doublet; $\mathrm{t}$, triplet; $\mathrm{m}$, multiplet; dd, doublet of doublets; dt, doublet of triplets; qt, quartet of triplets; ddt, doublet of doublet of triplets. Low-resolution electrospray mass spectral analyses were performed using a LC-MS (Advion Expression-L Compact MS, ESI source). High resolution mass spectral analyses (ESI-MS) were 
performed at the College of Chemistry Mass Spectrometry Facility at the University of California, Berkeley.

General Synthesis I for Conjugation of FA Trigger to Fluorophores. To an oven-dried 2-neck round-bottomed flask was added phenolic fluorophore (1.2 equiv) and $\mathrm{Cs}_{2} \mathrm{CO}_{3}$ (1.2 equiv) dissolved in anyhydrous DMF. The FA trigger ( 1 equiv) was added dropwise, and the solution was stirred under $\mathrm{N}_{2}$ at $40{ }^{\circ} \mathrm{C}$ for $12 \mathrm{~h}$. The DMF was removed under high vacuum, and purification by silica chromatography (EtOAc/hexanes) afforded the fluorophore conjugated to the azido-trigger.

General Synthesis II for Azide Reduction. To an oven-dried 2neck round-bottomed flask was added $\mathrm{SnCl}_{2}$ (1.5 equiv) and a solution of $\mathrm{PhSH}$ (4.5 equiv) and $\mathrm{Et}_{3} \mathrm{~N}$ (4.5 equiv) in $\mathrm{MeCN}$. The reaction mixture was stirred for $15 \mathrm{~min}$ at room temperature, then azideconjugated fluorophore (1 equiv) was added as a solution in $\mathrm{MeCN}$ and stirred at room temperature for an additional $12 \mathrm{~h}$. The reaction was concentrated under reduced pressure, diluted in $\mathrm{CH}_{2} \mathrm{Cl}_{2}$, and poured into $2 \mathrm{M} \mathrm{NaOH}$. The organic layer was extracted with $\mathrm{CH}_{2} \mathrm{Cl}_{2}$, dried over $\mathrm{Na}_{2} \mathrm{SO}_{4}$, filtered, and concentrated under reduced pressure. Purification by silica chromatography (EtOAc/hexanes) afforded the formaldehyde probe.

1-((tert-Butyldimethylsilyl)oxy)-3-methylhex-5-en-3-amine (2). A 2-neck flask was charged with $\mathbf{1}(213 \mu \mathrm{L}, 2.47 \mathrm{mmol})$, cooled to $0{ }^{\circ} \mathrm{C}$ and ammonia was added $(5.0 \mathrm{~mL}, 7.0 \mathrm{M}$ in $\mathrm{MeOH})$. After stirring for $30 \mathrm{~min}$, allyl pinacol boronate $(550 \mu \mathrm{L}, 2.96 \mathrm{mmol})$ was added dropwise, and the resulting solution stirred at room temperature for $24 \mathrm{~h}$. The volatiles were then removed under reduced pressure, and the residue was taken up in $1 \mathrm{M} \mathrm{HCl}$ and washed with $\mathrm{Et}_{2} \mathrm{O}(3 \times)$. The aqueous layer was then basified with $\mathrm{KOH}$ and extracted with $\mathrm{CH}_{2} \mathrm{Cl}_{2}$ $(3 \times)$. The combined organic layer was dried over $\mathrm{Na}_{2} \mathrm{SO}_{4}$, filtered and concentrated under reduced pressure to provide 2 as a colorless oil $(221 \mathrm{mg}, 69 \%) .{ }^{1} \mathrm{H}$ NMR $\left(400 \mathrm{MHz}, \mathrm{CDCl}_{3}\right) \delta 5.83$ (ddt, $J=17.6$, $10.3,7.5 \mathrm{~Hz}, 1 \mathrm{H}), 5.15-5.01(\mathrm{~m}, 2 \mathrm{H}), 3.77(\mathrm{t}, J=6.7 \mathrm{~Hz}, 2 \mathrm{H}), 2.13$ $(\mathrm{d}, J=7.5 \mathrm{~Hz}, 2 \mathrm{H}), 1.96(\mathrm{~s}, 2 \mathrm{H}), 1.61(\mathrm{t}, J=6.7 \mathrm{~Hz}, 2 \mathrm{H}), 1.23(\mathrm{~s}$, $2 \mathrm{H}), 1.08(\mathrm{~s}, 3 \mathrm{H}), 0.06(\mathrm{~d}, J=10.8 \mathrm{~Hz}, 9 \mathrm{H})$. LRMS calcd. for $\mathrm{C}_{13} \mathrm{H}_{29} \mathrm{NOSi}(\mathrm{M}+\mathrm{H})$ 244.20, found 244.2.

3-Azido-3-methylhex-5-en-1-ol (2-ii). To a solution of $\mathrm{CuSO}_{4}$. $5 \mathrm{H}_{2} \mathrm{O}(2.0 \mathrm{mg}, 7.7 \mu \mathrm{mol}), \mathrm{K}_{2} \mathrm{CO}_{3}(53.0 \mathrm{mg}, 0.39 \mathrm{mmol}), \mathrm{MeOH}(4.0$ $\mathrm{mL})$ and $2(100 \mathrm{mg}, 0.774 \mathrm{mmol})$ at room temperature was added Goddard's diazo transfer reagent $(161 \mathrm{mg}, 0.929 \mathrm{mmol})$, resulting in a change in color from blue to teal. The resulting slurry stirred at room temperature for $20 \mathrm{~h}$, after which the volatiles were removed under reduced pressure, and the residue was taken up in $1 \mathrm{M} \mathrm{HCl}$ and extracted with EtOAc $(3 \times)$. The combined organic layer was dried over $\mathrm{Na}_{2} \mathrm{SO}_{4}$, filtered, and concentrated to afford crude 2-ii as a colorless oil (crude, $116 \mathrm{mg}) .{ }^{1} \mathrm{H}$ NMR $\left(300 \mathrm{MHz}, \mathrm{CDCl}_{3}\right) \delta 5.81$ (ddt, $J=15.3,11.0,7.3 \mathrm{~Hz}, 1 \mathrm{H}), 5.23-5.10(\mathrm{~m}, 1 \mathrm{H}), 5.01(\mathrm{~s}, 1 \mathrm{H})$, $3.92(\mathrm{~s}, 1 \mathrm{H}), 3.79(\mathrm{t}, J=6.4 \mathrm{~Hz}, 1 \mathrm{H}), 3.06(\mathrm{~s}, 1 \mathrm{H}), 1.89-1.65(\mathrm{~m}$, $1 \mathrm{H}), 1.29(\mathrm{~d}, J=25.1 \mathrm{~Hz}, 3 \mathrm{H})$. LRMS calcd. for $\mathrm{C}_{7} \mathrm{H}_{13} \mathrm{~N}_{3} \mathrm{O}(\mathrm{M}+\mathrm{H})$ 155.10 , found 155.2 .

3-Azido-3-methylhex-5-en-1-yl 4-methylbenzenesulfonate (3). To a solution of crude 2-ii $(116 \mathrm{mg})$ in $\mathrm{CH}_{2} \mathrm{Cl}_{2}(3.75 \mathrm{~mL})$ was added $\mathrm{TsCl}(172 \mathrm{mg}, 0.900 \mathrm{mmol})$, DMAP $(9.0 \mathrm{mg}, 0.075 \mathrm{mmol})$, and $\mathrm{Et}_{3} \mathrm{~N}(125 \mu \mathrm{L}, 0.900 \mathrm{mmol})$. After stirring for $16 \mathrm{~h}$ at room temperature, the solution was poured into sat. aqueous $\mathrm{NH}_{4} \mathrm{Cl}$ and extracted with $\mathrm{CH}_{2} \mathrm{Cl}_{2}(3 \times)$. The combined organic layer was dried over $\mathrm{Na}_{2} \mathrm{SO}_{4}$, filtered, and concentrated under reduced pressure. Purification via column chromatography $(0 \rightarrow 10 \%$ EtOAc/hexanes gradient) afforded 4 as a colorless oil (64 mg, 27\% from 2$).{ }^{1} \mathrm{H}$ NMR $\left(300 \mathrm{MHz}, \mathrm{CDCl}_{3}\right) \delta 7.79(\mathrm{~d}, J=8.1 \mathrm{~Hz}, 2 \mathrm{H}), 7.36(\mathrm{~d}, J=8.1 \mathrm{~Hz}$, $2 \mathrm{H}), 5.85-5.64(\mathrm{~m}, 1 \mathrm{H}), 5.21-5.04(\mathrm{~m}, 2 \mathrm{H}), 4.13(\mathrm{t}, J=6.9 \mathrm{~Hz}, 2 \mathrm{H})$, $2.45(\mathrm{~s}, 4 \mathrm{H}), 2.25(\mathrm{~d}, J=7.3 \mathrm{~Hz}, 2 \mathrm{H}), 1.83(\mathrm{t}, J=8.1 \mathrm{~Hz}, 2 \mathrm{H}), 1.25(\mathrm{~s}$, $3 \mathrm{H}) .{ }^{13} \mathrm{C} \mathrm{NMR}\left(75 \mathrm{MHz}, \mathrm{CDCl}_{3}\right) \delta 162.44,145.09,132.91,132.05$, 130.05, 128.04, 119.97, 66.54, 44.45, 37.84, 23.47, 21.81. LRMS calcd. for $\mathrm{C}_{14} \mathrm{H}_{19} \mathrm{~N}_{3} \mathrm{O}_{3} \mathrm{~S}(\mathrm{M}+\mathrm{H})$ 310.11, found 310.4.

6-((3-Azido-3-methylhex-5-en-1-yl)oxy)-9-(4-methoxy-2methylphenyl)-3H-xanthen-3-one (5). Synthesized via general synthesis I described above $(46.8 \mathrm{mg}, 56 \%) .{ }^{1} \mathrm{H}$ NMR $(400 \mathrm{MHz}$, $\left.\mathrm{CDCl}_{3}\right) \delta 7.01(\mathrm{ddd}, J=38.6,20.6,11.2 \mathrm{~Hz}, 6 \mathrm{H}), 6.76(\mathrm{~d}, J=6.6 \mathrm{~Hz}$, $1 \mathrm{H}), 6.58(\mathrm{~d}, J=9.7 \mathrm{~Hz}, 1 \mathrm{H}), 6.45(\mathrm{~s}, 1 \mathrm{H}), 5.96-5.72(\mathrm{~m}, 1 \mathrm{H}), 5.29-$ $5.12(\mathrm{~m}, 2 \mathrm{H}), 4.21(\mathrm{t}, J=6.6 \mathrm{~Hz}, 2 \mathrm{H}), 3.89(\mathrm{~s}, 3 \mathrm{H}), 2.38(\mathrm{~d}, J=7.2$ $\mathrm{Hz}, 2 \mathrm{H}), 2.04$ (s, 5H), 1.37 (s, 3H). LRMS calcd. for $\mathrm{C}_{28} \mathrm{H}_{27} \mathrm{~N}_{3} \mathrm{O}_{4}(\mathrm{M}$ $+\mathrm{H}) 470.20$, found 470.5 .

6-((3-Amino-3-methylhex-5-en-1-yl)oxy)-9-(4-methoxy-2methylphenyl)-3H-xanthen-3-one (6). Synthesized via general synthesis II described above (6.3 mg, 91\%). ${ }^{1} \mathrm{H}$ NMR $(400 \mathrm{MHz}$, MeOD) $\delta 7.29(\mathrm{~d}, J=2.3 \mathrm{~Hz}, 1 \mathrm{H}), 7.27-7.12(\mathrm{~m}, 3 \mathrm{H}), 7.11-6.96(\mathrm{~m}$, $3 \mathrm{H}), 6.63(\mathrm{dd}, J=9.6,1.9 \mathrm{~Hz}, 1 \mathrm{H}), 6.48(\mathrm{~d}, J=1.9 \mathrm{~Hz}, 1 \mathrm{H}), 6.01-$ $5.86(\mathrm{~m}, 1 \mathrm{H}), 5.40-5.26(\mathrm{~m}, 2 \mathrm{H}), 4.39(\mathrm{t}, J=5.8 \mathrm{~Hz}, 2 \mathrm{H}), 3.90(\mathrm{~s}$, $3 \mathrm{H}), 2.52(\mathrm{~d}, J=7.4 \mathrm{~Hz}, 2 \mathrm{H}), 2.23(\mathrm{t}, J=5.7 \mathrm{~Hz}, 2 \mathrm{H}), 2.03(\mathrm{~s}, 3 \mathrm{H})$, $1.45(\mathrm{~s}, 3 \mathrm{H})$. LRMS calcd. for $\mathrm{C}_{28} \mathrm{H}_{29} \mathrm{NO}_{4}(\mathrm{M}+\mathrm{H})$ 444.21, found 444.2.

N-(1-((tert-Butyldimethylsilyl)oxy)-3-methylhex-5-en-3-yl)-4nitrobenzenesulfonamide (7). To a solution of 2 in $13 \mathrm{~mL} \mathrm{CH} \mathrm{Cl}_{2}$ in a $50 \mathrm{~mL}$ round-bottomed flask was added pyridine $(0.22 \mathrm{~mL}, 2.7$ $\mathrm{mmol})$ followed by 4-Nitrobenzenesulfonyl chloride $(0.60 \mathrm{~g}, 2.7$ $\mathrm{mmol}$ ) to form a deep orange solution. After stirring at room temperature for $24 \mathrm{~h}$, the reaction was poured into sat. $\mathrm{NH}_{4} \mathrm{Cl}$ (50 $\mathrm{mL}$ ), extracted with $\mathrm{CH}_{2} \mathrm{Cl}_{2}(3 \times)$, dried over $\mathrm{Na}_{2} \mathrm{SO}_{4}$, filtered, and concentrated under reduced pressure. Purification via column chromatography $(0 \rightarrow 30 \%$ EtOAc/hexanes gradient $)$ afforded 7 as a dark yellow oil $(65 \mathrm{mg}, 6 \%$ from 2$) .{ }^{1} \mathrm{H}$ NMR $\left(300 \mathrm{MHz}, \mathrm{CDCl}_{3}\right) \delta$ $8.37-8.24(\mathrm{~m}, 2 \mathrm{H}), 8.09-7.98(\mathrm{~m}, 2 \mathrm{H}), 6.78(\mathrm{~s}, 1 \mathrm{H}), 5.65(\mathrm{ddt}, J=$ 16.4, 10.6, 7.3 Hz, 1H), 5.11-4.97 (m, $2 \mathrm{H}), 3.82(\mathrm{pt}, J=6.7,3.4 \mathrm{~Hz}$, $2 \mathrm{H}), 2.60-2.39(\mathrm{~m}, 2 \mathrm{H}), 1.78-1.49(\mathrm{~m}, 3 \mathrm{H}), 1.22(\mathrm{~s}, 4 \mathrm{H}), 0.10(\mathrm{~d}, J$ $=10.9 \mathrm{~Hz}, 8 \mathrm{H})$. LRMS calcd. for $\mathrm{C}_{19} \mathrm{H}_{32} \mathrm{~N}_{2} \mathrm{O}_{5} \mathrm{SSi}(\mathrm{M}-\mathrm{H})$ 427.18, found 427.1 .

3-Methyl-3-(( $N$-methyl-4-nitrophenyl)sulfonamido)hex-5en-1-yl 4-methylbenzenesulfonate (8). A solution of $7(0.122 \mathrm{~g}$, $0.274 \mathrm{mmol}$ ) in $1 \mathrm{~mL}$ DMF was added to a $10 \mathrm{~mL}$ round-bottomed flask. Then, $\mathrm{K}_{2} \mathrm{CO}_{3}(0.075 \mathrm{~g}, 0.55 \mathrm{mmol})$ was added followed by dropwise addition of methyl iodide $(0.025 \mathrm{~mL}, 0.38 \mathrm{mmol})$. The reaction was stirred overnight at room temperature. The reaction mixture was partitioned between EtOAc and $\mathrm{H}_{2} \mathrm{O}$, washed with $\mathrm{H}_{2} \mathrm{O}$ $(3 \times)$, dried over $\mathrm{Na}_{2} \mathrm{SO}_{4}$, filtered, and concentrated under reduced pressure.

The concentrated material was resuspended in THF, placed in a 10 $\mathrm{mL}$ round-bottomed flask, and cooled to $0{ }^{\circ} \mathrm{C}$. Then, tetra- $n$ butylammonium fluoride ( $1.0 \mathrm{M}$ in THF, $0.27 \mathrm{~mL}, 0.28 \mathrm{mmol}$ ) was added dropwise to form a yellow solution that was warmed to roomtemperature and stirred for $16 \mathrm{~h}$. The reaction was poured into sat. $\mathrm{NH}_{4} \mathrm{Cl}(20 \mathrm{~mL})$, extracted with $\mathrm{CH}_{2} \mathrm{Cl}_{2}(3 \times)$, dried over $\mathrm{Na}_{2} \mathrm{SO}_{4}$, filtered, and concentrated under reduced pressure. Purification via column chromatography (45\% EtOAc/hexanes) afforded a yellow oil.

The oil was dissolved $\mathrm{CH}_{2} \mathrm{Cl}_{2}(1.5 \mathrm{~mL})$ and added to a $10 \mathrm{~mL}$ round-bottomed flask. Then, TsCl $(43 \mathrm{mg}, 0.23 \mathrm{mmol})$, DMAP $(2.5$ $\mathrm{mg}, 0.021 \mathrm{mmol})$, and $\mathrm{Et}_{3} \mathrm{~N}(30 \mu \mathrm{L}, 0.23 \mathrm{mmol})$. After stirring for $16 \mathrm{~h}$ at room temperature, the solution was poured into sat. aqueous $\mathrm{NH}_{4} \mathrm{Cl}$ and extracted with $\mathrm{CH}_{2} \mathrm{Cl}_{2}(3 \times)$. The combined organic layer was dried over $\mathrm{Na}_{2} \mathrm{SO}_{4}$, filtered, and concentrated under reduced pressure. Purification via column chromatography $(0 \rightarrow 35 \%$ EtOAc/ hexanes gradient) afforded 8 as a colorless oil (91 mg, 9.4\% from 2). ${ }^{1} \mathrm{H}$ NMR $\left(300 \mathrm{MHz}, \mathrm{CDCl}_{3}\right) \delta 8.41-8.21(\mathrm{~m}, 2 \mathrm{H}), 8.00-7.89(\mathrm{~m}$, $2 \mathrm{H}), 7.82-7.69(\mathrm{~m}, 2 \mathrm{H}), 7.35(\mathrm{~d}, J=8.0 \mathrm{~Hz}, 2 \mathrm{H}), 5.49(\mathrm{ddt}, J=17.2$, $10.2,7.2 \mathrm{~Hz}, 1 \mathrm{H}), 5.13-4.94(\mathrm{~m}, 2 \mathrm{H}), 4.21-3.97(\mathrm{~m}, 3 \mathrm{H}), 2.94(\mathrm{~s}$, $3 \mathrm{H}), 2.56(\mathrm{dd}, J=14.2,6.8 \mathrm{~Hz}, 1 \mathrm{H}), 2.45(\mathrm{~s}, 3 \mathrm{H}), 2.32(\mathrm{ddt}, J=21.3$, 14.1, $6.9 \mathrm{~Hz}, 3 \mathrm{H}), 2.04$ (s, 1H), 1.96 (dd, $J=14.7,7.3 \mathrm{~Hz}, 1 \mathrm{H}), 1.33$ $(\mathrm{s}, 3 \mathrm{H}), 1.25(\mathrm{t}, J=7.1 \mathrm{~Hz}, 1 \mathrm{H})$.

$\mathrm{N}$-(1-((9-(4-Methoxy-2-methylphenyl)-3-oxo-3H-xanthen-6yl)oxy)-3-methylhex-5-en-3-yl)- $N$-methyl-4-nitrobenzenesulfonamide (8-vi). Synthesized via general synthesis I described above. ${ }^{1} \mathrm{H}$ NMR $(300 \mathrm{MHz}, \mathrm{MeOD}) \delta 8.16(\mathrm{dd}, J=8.9,2.5 \mathrm{~Hz}, 2 \mathrm{H}), 8.04(\mathrm{~d}$, $J=8.8 \mathrm{~Hz}, 2 \mathrm{H}), 7.25-6.98(\mathrm{~m}, 5 \mathrm{H}), 6.90(\mathrm{t}, J=2.3 \mathrm{~Hz}, 1 \mathrm{H}), 6.78$ (ddd, $J=8.9,5.2,2.4 \mathrm{~Hz}, 1 \mathrm{H}), 6.63(\mathrm{dd}, J=9.6,2.1 \mathrm{~Hz}, 1 \mathrm{H}), 6.49(\mathrm{t}, J$ $=1.8 \mathrm{~Hz}, 1 \mathrm{H}), 5.80(\mathrm{dtd} J=15.7,8.0,6.1 \mathrm{~Hz}, 1 \mathrm{H}), 5.25-5.05(\mathrm{~m}$, $2 \mathrm{H}), 3.90(\mathrm{~s}, 5 \mathrm{H}), 3.13(\mathrm{~d}, J=1.2 \mathrm{~Hz}, 3 \mathrm{H}), 2.76(\mathrm{dt}, J=13.8,6.8 \mathrm{~Hz}$, $1 \mathrm{H}), 2.59-2.43(\mathrm{~m}, 1 \mathrm{H}), 2.34(\mathrm{dd}, J=14.2,7.5 \mathrm{~Hz}, 1 \mathrm{H}), 2.09-1.97$ $(\mathrm{m}, 4 \mathrm{H}), 1.53(\mathrm{~s}, 3 \mathrm{H}), 1.28(\mathrm{~s}, 1 \mathrm{H}), 0.98-0.82(\mathrm{~m}, 2 \mathrm{H})$. LRMS calcd. for $\mathrm{C}_{35} \mathrm{H}_{34} \mathrm{~N}_{2} \mathrm{O}_{8} \mathrm{~S}(\mathrm{M}+\mathrm{H})$ 643.20, found 643.3. 
9-(4-Methoxy-2-methylphenyl)-6-((3-methyl-3(methylamino)hex-5-en-1-yl)oxy)-3H-xanthen-3-one (9). To a solution of 8 -vi $(6.0 \mathrm{mg}, 9.0 \mu \mathrm{mol})$ in $\mathrm{MeCN}$, was added $\mathrm{K}_{2} \mathrm{CO}_{3}(5.5$ $\mathrm{mg}, 14 \mu \mathrm{mol})$ and thiophenol $(1.4 \mu \mathrm{L}, 14 \mu \mathrm{mol})$. The reaction mixture was heated at $50{ }^{\circ} \mathrm{C}$ for $16 \mathrm{~h}$. The reaction was then cooled, and directly purified by column chromatography $(0 \rightarrow 10 \% \mathrm{MeOH} /$ $\left.\mathrm{CH}_{2} \mathrm{Cl}_{2}\right)$ to give a yellow oil $(1.75 \mathrm{mg}, 42 \%) .{ }^{1} \mathrm{H}$ NMR $(400 \mathrm{MHz}$, $\left.\mathrm{CDCl}_{3}\right) \delta 7.11-6.96(\mathrm{~m}, 3 \mathrm{H}), 6.91(\mathrm{~d}, J=10.7 \mathrm{~Hz}, 2 \mathrm{H}), 6.78(\mathrm{~d}, J=$ $9.0 \mathrm{~Hz}, 1 \mathrm{H}), 6.60(\mathrm{~d}, J=9.7 \mathrm{~Hz}, 1 \mathrm{H}), 6.48(\mathrm{~s}, 1 \mathrm{H}), 5.84(\mathrm{dd}, J=16.8$, $8.9 \mathrm{~Hz}, 1 \mathrm{H}), 5.28-5.09(\mathrm{~m}, 2 \mathrm{H}), 4.26(\mathrm{t}, J=6.8 \mathrm{~Hz}, 2 \mathrm{H}), 3.90(\mathrm{~s}$, $2 \mathrm{H}), 2.45(\mathrm{~s}, 2 \mathrm{H}), 2.36(\mathrm{~d}, J=7.4 \mathrm{~Hz}, 1 \mathrm{H}), 2.04(\mathrm{~s}, 4 \mathrm{H}), 1.26(\mathrm{~s}, 7 \mathrm{H})$. LRMS calcd. for $\mathrm{C}_{29} \mathrm{H}_{31} \mathrm{NO}_{4}(\mathrm{M}+\mathrm{H}) 458.22$, found 458.3 .

9-(4-Methoxy-2-methylphenyl)-6-((3-methyl-3-((2,2,2trifluoroethyl)amino)hex-5-en-1-yl)oxy)-3H-xanthen-3-one (10). A solution of 6 in $0.4 \mathrm{~mL}$ DMF was added to a dry $5 \mathrm{~mL}$ roundbottomed flask. Then, $\mathrm{K}_{2} \mathrm{CO}_{3}(14.8 \mathrm{mg}, 0.107 \mathrm{mmol})$ was added, followed by 2,2,2-trifluoroethyl trifluoromethanesulfonate $(74 \mu \mathrm{L}$ of a $7 \mathrm{M}$ solution in $\mathrm{MeCN}, 0.052 \mathrm{mmol}$ ). The reaction was stirred for $5 \mathrm{~h}$ at room temperature. Additional 2,2,2-trifluoroethyl trifluoromethanesulfonate $(74 \mu \mathrm{L}$ of a $7 \mathrm{M}$ solution in $\mathrm{MeCN}, 0.052 \mathrm{mmol}$ ) was added, and the reaction was stirred for $24 \mathrm{~h}$. The solvent was removed under reduced pressure, and purification via column chromatography $(0 \rightarrow$ $15 \% \mathrm{MeOH} / \mathrm{CHCl}_{3}$ gradient) afforded 10 as a yellow solid $(5.1 \mathrm{mg}$, 23\%) ${ }^{1} \mathrm{H}$ NMR $\left(400 \mathrm{MHz}, \mathrm{CDCl}_{3}\right) \delta 7.18-6.86(\mathrm{~m}, 5 \mathrm{H}), 6.78(\mathrm{dd}, J$ $=8.9,2.4 \mathrm{~Hz}, 1 \mathrm{H}), 6.61(\mathrm{dd}, J=9.7,2.0 \mathrm{~Hz}, 1 \mathrm{H}), 6.50(\mathrm{~d}, J=1.9 \mathrm{~Hz}$, $1 \mathrm{H}), 5.80$ (ddt, $J=17.5,10.5,7.1 \mathrm{~Hz}, 1 \mathrm{H}), 5.24-5.11(\mathrm{~m}, 2 \mathrm{H}), 4.37-$ $4.11(\mathrm{~m}, 2 \mathrm{H}), 3.90(\mathrm{~s}, 3 \mathrm{H}), 3.28(\mathrm{dq}, J=14.4,9.3 \mathrm{~Hz}, 1 \mathrm{H}), 3.12(\mathrm{dq}, J$ $=14.5,9.3 \mathrm{~Hz}, 1 \mathrm{H}), 2.97(\mathrm{p}, J=5.8 \mathrm{~Hz}, 1 \mathrm{H}), 2.28(\mathrm{~h}, J=7.1,6.5 \mathrm{~Hz}$, $2 \mathrm{H}), 2.05(\mathrm{~s}, 4 \mathrm{H}), 1.88-1.68(\mathrm{~m}, 5 \mathrm{H}), 1.26(\mathrm{~s}, 2 \mathrm{H})$. LRMS calcd. for $\mathrm{C}_{29} \mathrm{H}_{28} \mathrm{~F}_{3} \mathrm{NO}_{4}(\mathrm{M}+\mathrm{H})$ 526.21, found 526.0.

1-Hydroxyhex-5-en-3-aminium chloride (12). A solution of 11 $((S)$-3-Boc-amino-5-hexenoic acid $)(1.40 \mathrm{~g}, 6.11 \mathrm{mmol})$ was dissolved in dry THF $(21 \mathrm{~mL})$ and cooled to $0{ }^{\circ} \mathrm{C}$. To the resulting solution was added $\mathrm{Et}_{3} \mathrm{~N}(1.70 \mathrm{~mL}, 12.2 \mathrm{mmol})$ and ethyl chloroformate $(0.70 \mathrm{~mL}$, $7.3 \mathrm{mmol}$ ), causing a white precipitate to form, and the reaction was filtered after stirring for $30 \mathrm{~min}$ at $0{ }^{\circ} \mathrm{C}$. After cooling the filtrate to 0 ${ }^{\circ} \mathrm{C}, \mathrm{NaBH}_{4}(462 \mathrm{mg}, 12.2 \mathrm{mmol})$ and $\mathrm{H}_{2} \mathrm{O}(2 \mathrm{~mL})$ were added, and the resulting mixture stirred for $2 \mathrm{~h}$ at room temperature. The reaction was quenched with sat aq $\mathrm{NH}_{4} \mathrm{Cl}$, the THF was removed under reduced pressure, and the resulting solution was extracted with EtOAc $(3 \times)$. The combined organic layer was washed with $\mathrm{H}_{2} \mathrm{O}, 1 \mathrm{M}$ aq $\mathrm{NaOH}$, and brine, then dried over $\mathrm{Na}_{2} \mathrm{SO}_{4}$, filtered, and concentrated under reduced pressure. Purification via column chromatography $(5 \rightarrow$ $20 \% \mathrm{EtOAc} /$ hexanes) provided 12 as a colorless oil $(0.944 \mathrm{~g}, 72 \%)$. ${ }^{1} \mathrm{H}$ NMR (400 MHz, MeOD) $\delta 5.93-5.72(\mathrm{~m}, 1 \mathrm{H}), 5.33-5.18(\mathrm{~m}$, $2 \mathrm{H}), 5.00-4.86(\mathrm{~m}, 3 \mathrm{H}), 3.89-3.66(\mathrm{~m}, 2 \mathrm{H}), 3.42(\mathrm{t}, J=6.8 \mathrm{~Hz}, 1 \mathrm{H})$, 3.33-3.27 (m, 1H), 2.55-2.37 (m, 2H), 1.95-1.71 (m, 2H). LRMS calcd. for $\mathrm{C}_{6} \mathrm{H}_{14} \mathrm{ClNO}(\mathrm{M}+\mathrm{H}) 152.07$, found 152.1 .

3-Azidohex-5-en-1-yl 4-methylbenzenesulfonate (13). To a solution of $\mathrm{CuSO}_{4} \cdot 5 \mathrm{H}_{2} \mathrm{O}(7.0 \mathrm{mg}, 0.03 \mathrm{mmol}), \mathrm{K}_{2} \mathrm{CO}_{3}(850 \mathrm{mg}, 6.16$ $\mathrm{mmol}), \mathrm{MeOH}(12 \mathrm{~mL})$ and 12 at room temperature was added Goddard's diazo transfer reagent $(573 \mathrm{mg}, 2.74 \mathrm{mmol})$, resulting in a change in color from blue to teal. The resulting slurry stirred at room temperature for $14 \mathrm{~h}$, after which the volatiles were removed under reduced pressure, and the residue was taken up in $1 \mathrm{M} \mathrm{HCl}$ and extracted with EtOAc $(3 \times)$. The combined organic layer was dried over $\mathrm{Na}_{2} \mathrm{SO}_{4}$, filtered, and concentrated under reduced pressure to afford crude 12-iii as a colorless oil that was used directly in the next step.

To a solution of crude 12-iii in $\mathrm{CH}_{2} \mathrm{Cl}_{2}(10 \mathrm{~mL})$ was added $\mathrm{TsCl}$ (625 mg, $3.28 \mathrm{mmol}$ ), DMAP (107 mg, $0.876 \mathrm{mmol}$ ), and $\mathrm{Et}_{3} \mathrm{~N}$ (457 $\mu \mathrm{L}, 3.28 \mathrm{mmol}$ ). After stirring for $24 \mathrm{~h}$ at room temperature, the solution was poured into sat. aqueous $\mathrm{NH}_{4} \mathrm{Cl}$ and extracted with $\mathrm{CH}_{2} \mathrm{Cl}_{2}(3 \times)$. The combined organic layer was dried over $\mathrm{Na}_{2} \mathrm{SO}_{4}$, filtered, and concentrated under reduced presuure. Purification via column chromatography $(0 \rightarrow 20 \% \mathrm{EtOAc} /$ hexanes gradient $)$ afforded 13 as a colorless oil (353 mg, 53\% from 11-i). ${ }^{1} \mathrm{H}$ NMR $(400 \mathrm{MHz}$, $\left.\mathrm{CDCl}_{3}\right) \delta 7.79(\mathrm{~d}, J=8.2 \mathrm{~Hz}, 2 \mathrm{H}), 7.35(\mathrm{~d}, J=8.1 \mathrm{~Hz}, 2 \mathrm{H}), 5.74(\mathrm{ddt}$, $J=16.4,10.6,7.0 \mathrm{~Hz}, 1 \mathrm{H}), 5.21-5.07(\mathrm{~m}, 2 \mathrm{H}), 4.17-4.03(\mathrm{~m}, 2 \mathrm{H})$, $3.50(\mathrm{dtd}, J=10.1,6.4,3.7 \mathrm{~Hz}, 1 \mathrm{H}), 2.44(\mathrm{~s}, 3 \mathrm{H}), 2.36-2.22(\mathrm{~m}, 2 \mathrm{H})$,
1.88 (dddd, $J=14.7,8.3,6.3,3.7 \mathrm{~Hz}, 1 \mathrm{H}), 1.62(\mathrm{ddt}, J=14.6,9.6,4.6$ $\mathrm{Hz}, 1 \mathrm{H}) .{ }^{13} \mathrm{C} \mathrm{NMR}(101 \mathrm{MHz}, \mathrm{CDCl} 3) \delta 145.13,132.90,132.75$, $130.02,127.97,119.10,67.08,58.03,38.82,33.23,21.72$. LRMS calcd. for $\mathrm{C}_{13} \mathrm{H}_{17} \mathrm{~N}_{3} \mathrm{O}_{3} \mathrm{~S}(\mathrm{M}+\mathrm{H}) 296.09$, found 296.4.

6-((3-Azidohex-5-en-1-yl)oxy)-9-(4-methoxy-2-methylphenyl)-3H-xanthen-3-one (13-v). Synthesized via general synthesis I described above (46.3 mg, 58\%). ${ }^{1} \mathrm{H}$ NMR (300 $\left.\mathrm{MHz}, \mathrm{CDCl}_{3}\right) \delta$ $7.15-6.83(\mathrm{~m}, 6 \mathrm{H}), 6.77(\mathrm{dd}, J=8.9,2.5 \mathrm{~Hz}, 1 \mathrm{H}), 6.57(\mathrm{dd}, J=9.7$, $1.9 \mathrm{~Hz}, 1 \mathrm{H}), 6.44(\mathrm{~d}, J=2.0 \mathrm{~Hz}, 1 \mathrm{H}), 5.85(\mathrm{ddt}, J=17.1,10.2,7.0 \mathrm{~Hz}$, $1 \mathrm{H}), 5.29-5.07(\mathrm{~m}, 2 \mathrm{H}), 4.32-4.11(\mathrm{~m}, 2 \mathrm{H}), 3.89(\mathrm{~s}, 3 \mathrm{H}), 3.79-3.55$ $(\mathrm{m}, 1 \mathrm{H}), 2.53-2.31(\mathrm{~m}, 2 \mathrm{H}), 2.04(\mathrm{~s}, 3 \mathrm{H}), 1.89$ (ddt, $J=14.5,9.6,4.9$ $\mathrm{Hz}, 1 \mathrm{H})$. LRMS calcd. for $\mathrm{C}_{27} \mathrm{H}_{25} \mathrm{~N}_{3} \mathrm{O}_{4}(\mathrm{M}+\mathrm{H}) 456.18$, found 456.2.

6-((3-Aminohex-5-en-1-yl)oxy)-9-(4-methoxy-2-methylphenyl)-3H-xanthen-3-one (14). Synthesized via general synthesis II described above (7.2 mg, 33\%). ${ }^{1} \mathrm{H}$ NMR (400 MHz, MeOD) $\delta$ 7.15-6.94 (m, 5H), 6.85-6.70 (m, $2 \mathrm{H}), 6.60(\mathrm{dd}, J=9.3,2.2 \mathrm{~Hz}$, $1 \mathrm{H}), 6.54(\mathrm{~d}, J=2.2 \mathrm{~Hz}, 1 \mathrm{H}), 5.87(\mathrm{ddt}, J=17.2,10.0,7.0 \mathrm{~Hz}, 1 \mathrm{H})$, 5.21-5.01 (m, 2H), $3.95(\mathrm{~s}, 1 \mathrm{H}), 3.89(\mathrm{~s}, 3 \mathrm{H}), 3.73-3.55(\mathrm{~m}, 2 \mathrm{H})$, $2.55-2.28(\mathrm{~m}, 2 \mathrm{H}), 2.02(\mathrm{~d}, J=1.3 \mathrm{~Hz}, 3 \mathrm{H}), 1.90$ (dddd, $J=14.1,8.0$, $6.1,4.7 \mathrm{~Hz}, 1 \mathrm{H}), 1.76(\mathrm{ddt}, J=14.0,8.4,5.4 \mathrm{~Hz}, 1 \mathrm{H})$. LRMS calcd. for $\mathrm{C}_{27} \mathrm{H}_{27} \mathrm{NO}_{4}(\mathrm{M}+\mathrm{H})$ 430.19, found 430.2.

3-Azido-3-phenylhex-5-en-1-ol (15-viii). To an oven-dried 25 $\mathrm{mL} 2$-neck round-bottomed flask was added $4 \mathrm{~mL}$ of a $7 \mathrm{M} \mathrm{NH}_{3}$ solution in $\mathrm{MeOH}$. The solution was cooled to $0{ }^{\circ} \mathrm{C}$ and $15(0.53 \mathrm{mg}$, $2.77 \mathrm{mmol}$ ) was added. The reaction was warmed to room temperature and stirred for $30 \mathrm{~min}$. The reaction was again cooled to $0{ }^{\circ} \mathrm{C}$, and then allyl pinacol boronate was added as a solution in $\mathrm{CHCl}_{3}$. The reaction mixture was stirred at room temperature for 12 $h$. The reaction was concentrated under reduced pressure, then diluted in $0.1 \mathrm{M} \mathrm{NaOH}$, and extracted with $\mathrm{Et}_{2} \mathrm{O}(3 \times)$. The combined organic layers were washed with brine, dried over $\mathrm{Na}_{2} \mathrm{SO}_{4}$, filtered, and concentrated under reduced pressure to afford a light yellow oil.

The oil was dissolved in $12 \mathrm{~mL} \mathrm{MeOH}$ and added to a $100 \mathrm{~mL}$ round-bottomed flask. Then, $\mathrm{CuSO}_{4} \cdot 5 \mathrm{H}_{2} \mathrm{O}(7 \mathrm{mg}, 0.03 \mathrm{mmol})$ and $\mathrm{K}_{2} \mathrm{CO}_{3}(0.651 \mathrm{~g}, 4.71 \mathrm{mmol})$, followed by Goddard's diazo transfer reagent $(0.7 \mathrm{~g}, 3.32 \mathrm{mmol})$ was added. After stirring for $12 \mathrm{~h}$, the reaction was concentrated under reduced pressure, partitioned between EtOAc and $1 \mathrm{M} \mathrm{HCl}$, and extracted with EtOAc $(3 \times)$. The combined organic layers were washed with $1 \mathrm{M} \mathrm{HCl}$, brine, dried over $\mathrm{Na}_{2} \mathrm{SO}_{4}$, and concentrated under reduced pressure. Purification by silica gel chromatography (25\% EtOAc/hexanes) afforded a clear oil $(0.47 \mathrm{~g}, 78 \%) .{ }^{1} \mathrm{H}$ NMR $\left(400 \mathrm{MHz}, \mathrm{CDCl}_{3}\right) \delta 7.41(\mathrm{~d}, J=4.3 \mathrm{~Hz}$, $4 \mathrm{H}), 7.32(\mathrm{~h}, J=4.2 \mathrm{~Hz}, 1 \mathrm{H}), 5.66(\mathrm{ddt}, J=17.2,10.2,7.1 \mathrm{~Hz}, 1 \mathrm{H})$, $5.26-5.06(\mathrm{~m}, 2 \mathrm{H}), 3.61$ (ddd, $J=11.0,8.0,6.2 \mathrm{~Hz}, 1 \mathrm{H}), 3.46$ (ddd, $J$ $=10.9,8.0,5.8 \mathrm{~Hz}, 1 \mathrm{H}), 2.81(\mathrm{t}, J=7.3 \mathrm{~Hz}, 3 \mathrm{H}), 2.24$ (qdd, $J=14.1$, $8.0,6.0 \mathrm{~Hz}, 2 \mathrm{H})$.

3-Azido-3-phenylhex-5-en-1-yl 4-methylbenzenesulfonate (16). To an oven-dried $25 \mathrm{~mL}$ 2-neck round-bottomed flask was added 3-azido-3-phenylhex-5-en-1-ol $(0.240 \mathrm{~g}, 1.1 \mathrm{mmol})$ as a solution in $6 \mathrm{~mL} \mathrm{CH} \mathrm{Cl}_{2}, p$-Toluenesulfonyl chloride $(0.316 \mathrm{~g}, 1.6 \mathrm{mmol})$, DMAP $(0.068 \mathrm{~g}, 0.55 \mathrm{mmol})$, and $\mathrm{NEt}_{3}(0.23 \mathrm{~mL}, 1.6 \mathrm{mmol})$. The reaction mixture was stirred for $16 \mathrm{~h}$ at room temperature. The reaction mixture was concentrated under reduced pressure, and purification by silica column chromatography ( $5 \%$ EtOAc/hexanes) afforded 16 (0.41 g, quantitative). ${ }^{1} \mathrm{H}$ NMR (400 $\left.\mathrm{MHz}, \mathrm{CDCl}_{3}\right) \delta$ $7.77-7.70(\mathrm{~m}, 2 \mathrm{H}), 7.47-7.25(\mathrm{~m}, 7 \mathrm{H}), 5.58(\mathrm{ddt}, J=17.2,10.2,7.0$ $\mathrm{Hz}, 1 \mathrm{H}), 5.20-5.07(\mathrm{~m}, 2 \mathrm{H}), 4.10-3.99(\mathrm{~m}, 1 \mathrm{H}), 3.91-3.80(\mathrm{~m}, 1 \mathrm{H})$ $2.74(\mathrm{~d}, J=7.1 \mathrm{~Hz}, 2 \mathrm{H}), 2.46(\mathrm{~s}, 3 \mathrm{H}), 2.34$ (ddd, $J=8.1,6.5,1.6 \mathrm{~Hz}$, $2 \mathrm{H}) .{ }^{13} \mathrm{C}$ NMR $\left(101 \mathrm{MHz}, \mathrm{CDCl}_{3}\right) \delta 144.85,139.84,132.64,131.39$, $129.82,128.68,127.80,127.68,125.66,125.60,119.74,67.22,66.26$, 44.46, 44.36, 38.08, 21.57. LRMS calcd. for $\mathrm{C}_{19} \mathrm{H}_{21} \mathrm{~N}_{3} \mathrm{O}_{3} \mathrm{~S}(\mathrm{M}+\mathrm{H})$ 372.13 , found 372.2 .

6-((3-Amino-3-phenylhex-5-en-1-yl)oxy)-9-(4-methoxy-2methylphenyl)-3H-xanthen-3-one (17). Synthesized via general synthesis I (48 mg, 33\%) and II (16.8 mg, 74\%) described above. ${ }^{1} \mathrm{H}$

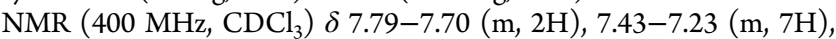
5.58 (ddt, $J=17.2,10.2,7.0 \mathrm{~Hz}, 1 \mathrm{H}), 5.26-5.04(\mathrm{~m}, 2 \mathrm{H}), 4.16-3.96$ $(\mathrm{m}, 1 \mathrm{H}), 3.93-3.79(\mathrm{~m}, 1 \mathrm{H}), 2.74(\mathrm{~d}, J=7.1 \mathrm{~Hz}, 2 \mathrm{H}), 2.46(\mathrm{~s}, 3 \mathrm{H})$, 2.34 (ddd, $J=8.1,6.5,1.6 \mathrm{~Hz}, 2 \mathrm{H})$. LRMS calcd. for $\mathrm{C}_{33} \mathrm{H}_{31} \mathrm{NO}_{4}(\mathrm{M}+$ H) 506.23, found 506.2. 
3-Amino-3,4,4-trimethylhex-5-en-1-ol (20). To an oven-dried $250 \mathrm{~mL}$ 2-neck round-bottomed flask equipped with a $100 \mathrm{~mL}$ addition funnel was cannulated $60 \mathrm{~mL}$ of a $7 \mathrm{M} \mathrm{NH}_{3}$ solution in $\mathrm{MeOH}$. The solution was cooled to $0{ }^{\circ} \mathrm{C}$ and the ketone $(1.7 \mathrm{~mL}, 20$ mmol) was added. The reaction was warmed to room temperature and stirred for $1 \mathrm{~h}$. The reaction was again cooled to $0{ }^{\circ} \mathrm{C}$, and the previously prepared (3-methylbut-2-en-1-yl)boronic acid was added as a solution in $\mathrm{CHCl}_{3}$. The reaction mixture was stirred at room temperature for $24 \mathrm{~h}$. The reaction was diluted in $1 \mathrm{M} \mathrm{HCl}(100 \mathrm{~mL})$, washed with EtOAc $(3 \times)$, basified with $\mathrm{NaOH}$, and extracted with $\mathrm{DCM}(3 \times)$. The combined organic layers were dried over $\mathrm{Na}_{2} \mathrm{SO}_{4}$, filtered, and concentrated under reduced pressure to afford a clear oil $(2.31 \mathrm{~g}, 74 \%) .{ }^{1} \mathrm{H}$ NMR $\left(400 \mathrm{MHz}, \mathrm{CDCl}_{3}\right) \delta 5.71$ (dd, $J=17.5,10.9$ $\mathrm{Hz}, 1 \mathrm{H}), 4.91-4.69(\mathrm{~m}, 2 \mathrm{H}), 3.68(\mathrm{t}, J=12.5 \mathrm{~Hz}, 1 \mathrm{H}), 3.45(\mathrm{~d}, J=7.8$ $\mathrm{Hz}, 1 \mathrm{H}), 2.74(\mathrm{~s}, 2 \mathrm{H}), 1.50(\mathrm{t}, J=15.0 \mathrm{~Hz}, 1 \mathrm{H}), 1.23(\mathrm{~d}, J=17.1 \mathrm{~Hz}$, $1 \mathrm{H}), 0.89(\mathrm{~s}, 3 \mathrm{H}), 0.77(\mathrm{~s}, 6 \mathrm{H}) .{ }^{13} \mathrm{C}$ NMR $\left(101 \mathrm{MHz}, \mathrm{CDCl}_{3}\right) \delta$ 144.29, 113.24, 59.62, 43.79, 40.51, 35.12, 21.64, 20.86, 19.60. LRMS calcd. for $\mathrm{C}_{9} \mathrm{H}_{19} \mathrm{NO}(\mathrm{M}+\mathrm{H}) 158.15$, found 158.3 .

3-Azido-3,4,4-trimethylhex-5-en-1-ol (20-iii). To an oven-dried $250 \mathrm{~mL}$ 2-neck round-bottomed flask was added $\mathrm{CuSO}_{4} \cdot 5 \mathrm{H}_{2} \mathrm{O}(33.9$ $\mathrm{mg}, 0.136 \mathrm{mmol})$ and $\mathrm{K}_{2} \mathrm{CO}_{3}(2.82 \mathrm{~g}, 20.4 \mathrm{mmol})$ dissolved in $\mathrm{MeOH}$ $(130 \mathrm{~mL})$. Then, 20 was added as a solution in $10 \mathrm{~mL} \mathrm{MeOH}$, followed by Goddard's diazo transfer reagent $(3.41 \mathrm{~g}, 16.3 \mathrm{mmol})$. The resulting teal slurry was stirred at room temperature for $18 \mathrm{~h}$. The solvent was removed under reduced pressure. The residue was partitioned between EtOAc $(75 \mathrm{~mL})$ and $1 \mathrm{M} \mathrm{HCl}(75 \mathrm{~mL})$ and extracted with EtOAc $(2 \times 100 \mathrm{~mL})$. The combined organic layers were dried over $\mathrm{Na}_{2} \mathrm{SO}_{4}$, filtered, and concentrated under reduced pressure. Purification by silica column chromatography (20\% EtOAc/ hexanes) afforded a colorless liquid (720 mg, 29\%). ${ }^{1} \mathrm{H}$ NMR (400 $\left.\mathrm{MHz}, \mathrm{CDCl}_{3}\right) \delta 5.92(\mathrm{dd}, J=17.4,10.9 \mathrm{~Hz}, 1 \mathrm{H}), 5.12-4.94(\mathrm{~m}, 2 \mathrm{H})$, $3.73(\mathrm{qt}, J=10.7,6.9 \mathrm{~Hz}, 2 \mathrm{H}), 2.69(\mathrm{~s}, 1 \mathrm{H}), 1.85(\mathrm{dt}, J=14.1,7.0 \mathrm{~Hz}$, $1 \mathrm{H}), 1.73-1.55(\mathrm{dt}, 1 \mathrm{H}), 1.29(\mathrm{~s}, 3 \mathrm{H}), 1.04(\mathrm{~s}, 6 \mathrm{H}) .{ }^{13} \mathrm{C}$ NMR $(101$ $\left.\mathrm{MHz}, \mathrm{CDCl}_{3}\right) \delta 143.81,113.80,67.71,59.26,45.53,37.94,22.37$, 22.22, 17.80. LRMS calcd. for $\mathrm{C}_{9} \mathrm{H}_{17} \mathrm{~N}_{3} \mathrm{O}(\mathrm{M}+\mathrm{H})$ 184.14, found 184.3.

3-Azido-3,4,4-trimethylhex-5-en-1-yl 4-methylbenzenesulfonate (21). To an oven-dried $100 \mathrm{~mL}$ 2-neck round-bottomed flask was added 3-Azido-3,4,4-trimethylhex-5-en-1-ol (700 mg, 3.81 mmol) as a solution in $50 \mathrm{~mL} \mathrm{CH}_{2} \mathrm{Cl}_{2}, p$-Toluenesulfonyl chloride $(1.09 \mathrm{~g}, 5.72 \mathrm{mmol})$, DMAP $(186 \mathrm{mg}, 1.52 \mathrm{mmol})$, and $\mathrm{Et}_{3} \mathrm{~N}(0.79$ $\mathrm{mL}, 5.7 \mathrm{mmol})$. The reaction mixture was stirred for $16 \mathrm{~h}$ at room temperature. The mixture was poured into saturated $\mathrm{NH}_{4} \mathrm{Cl}(60 \mathrm{~mL})$ and extracted with $\mathrm{CH}_{2} \mathrm{Cl}_{2}(3 \times)$. The combined organic layers were dried over $\mathrm{Na}_{2} \mathrm{SO}_{4}$, filtered, and concentrated under reduced pressure. Purification by silica column chromatography ( $5 \%$ EtOAc/hexanes) afforded a colorless oil $(187 \mathrm{mg}, 15 \%) .{ }^{1} \mathrm{H}$ NMR $\left(400 \mathrm{MHz}, \mathrm{CDCl}_{3}\right) \delta$ $7.77(\mathrm{~d}, J=8.1 \mathrm{~Hz}, 2 \mathrm{H}), 7.33(\mathrm{~d}, J=8.0 \mathrm{~Hz}, 2 \mathrm{H}), 5.84(\mathrm{dd}, J=17.4$, $10.9 \mathrm{~Hz}, 1 \mathrm{H}), 5.09-4.90(\mathrm{~m}, 2 \mathrm{H}), 4.20-4.04(\mathrm{~m}, 2 \mathrm{H}), 2.42(\mathrm{~s}, 3 \mathrm{H})$, $1.81(\mathrm{ddt}, J=42.9,14.5,6.9 \mathrm{~Hz}, 2 \mathrm{H}), 1.23(\mathrm{~s}, 3 \mathrm{H}), 0.99(\mathrm{~s}, 6 \mathrm{H}) .{ }^{13} \mathrm{C}$ NMR $\left(101 \mathrm{MHz}, \mathrm{CDCl}_{3}\right) \delta 144.95,143.26,129.91,127.87,114.14$, 67.42, 66.78, 45.52, 34.63, 22.23, 22.03, 21.60, 17.72. LRMS calcd. for $\mathrm{C}_{16} \mathrm{H}_{23} \mathrm{~N}_{3} \mathrm{O}_{3} \mathrm{~S}(\mathrm{M}+\mathrm{H})$ 338.15, found 338.2 .

FAP488. Synthesized via general synthesis I (11.8 mg, 24\%) and II (6.8 mg, 33\%) described above. ${ }^{1} \mathrm{H}$ NMR $(400 \mathrm{MHz}, \mathrm{MeOD}) \delta 7.65-$ $7.51(\mathrm{~m}, 3 \mathrm{H}), 7.32(\mathrm{dd}, J=9.3,2.3 \mathrm{~Hz}, 1 \mathrm{H}), 7.24(\mathrm{dd}, J=8.4,1.0 \mathrm{~Hz}$, $1 \mathrm{H}), 7.21-7.11(\mathrm{~m}, 3 \mathrm{H}), 7.07(\mathrm{dd}, J=8.5,2.5 \mathrm{~Hz}, 1 \mathrm{H}), 6.07(\mathrm{dd}, J=$ $17.3,10.8 \mathrm{~Hz}, 1 \mathrm{H}), 5.40-5.25(\mathrm{~m}, 2 \mathrm{H}), 4.56(\mathrm{t}, J=6.2 \mathrm{~Hz}, 2 \mathrm{H}), 3.93$ (s, 3H), 2.46-2.26 (m, 2H), $2.04(\mathrm{~s}, 3 \mathrm{H}), 1.47(\mathrm{~s}, 3 \mathrm{H}), 1.23(\mathrm{~s}, 6 \mathrm{H})$. LRMS calcd. for $\mathrm{C}_{30} \mathrm{H}_{33} \mathrm{NO}_{4}(\mathrm{M}+\mathrm{H}) 472.24$, found 472.2 .

FAP385 Azide. Synthesized via general synthesis I described above $(21.3 \mathrm{mg}, 61 \%) .{ }^{1} \mathrm{H}$ NMR $\left(400 \mathrm{MHz}, \mathrm{CDCl}_{3}\right) \delta 7.62(\mathrm{~d}, J=10.7 \mathrm{~Hz}$, $1 \mathrm{H}), 6.99-6.85(\mathrm{~m}, 2 \mathrm{H}), 6.62(\mathrm{~s}, 1 \mathrm{H}), 5.98(\mathrm{dd}, J=17.4,10.9 \mathrm{~Hz}$, $1 \mathrm{H}), 5.19-5.02(\mathrm{~m}, 2 \mathrm{H}), 4.18(\mathrm{t}, J=6.8 \mathrm{~Hz}, 2 \mathrm{H}), 2.23-1.84(\mathrm{~m}, 2 \mathrm{H})$, $1.40(\mathrm{~s}, 3 \mathrm{H}), 1.11(\mathrm{~s}, 6 \mathrm{H})$.

FAP385. Synthesized via general synthesis II described above (20.2 $\mathrm{mg}, 99 \%) .{ }^{1} \mathrm{H}$ NMR $\left(400 \mathrm{MHz}, \mathrm{CDCl}_{3}\right) \delta 7.66-7.56(\mathrm{~m}, 1 \mathrm{H}), 6.97-$ $6.86(\mathrm{~m}, 2 \mathrm{H}), 6.60(\mathrm{~s}, 1 \mathrm{H}), 5.99(\mathrm{dd}, J=17.5,10.9 \mathrm{~Hz}, 1 \mathrm{H}), 5.19-$ $4.98(\mathrm{~m}, 2 \mathrm{H}), 4.37-4.15(\mathrm{~m}, 2 \mathrm{H}), 2.08-1.82(\mathrm{~m}, 2 \mathrm{H}), 1.42(\mathrm{~s}, 2 \mathrm{H})$, $1.10(\mathrm{~s}, 3 \mathrm{H}), 1.06(\mathrm{~s}, 6 \mathrm{H})$. HRMS calcd. for $\mathrm{C}_{19} \mathrm{H}_{22} \mathrm{~F}_{3} \mathrm{NO}_{3}(\mathrm{M}+\mathrm{H})$ 370.1552 , found 370.1621 .

FAP498 Azide. Synthesized via general synthesis I described above (50.1 mg, 99\%). ${ }^{1} \mathrm{H}$ NMR $\left(400 \mathrm{MHz}, \mathrm{CDCl}_{3}\right) \delta 7.37(\mathrm{~d}, J=5.5 \mathrm{~Hz}$, $1 \mathrm{H}), 6.95-6.75(\mathrm{~m}, 1 \mathrm{H}), 6.71(\mathrm{~d}, J=2.5 \mathrm{~Hz}, 0 \mathrm{H}), 6.59(\mathrm{dd}, J=8.9$, $2.5 \mathrm{~Hz}, 0 \mathrm{H}), 6.52-6.46(\mathrm{~m}, 0 \mathrm{H}), 6.38(\mathrm{~d}, J=8.6 \mathrm{~Hz}, 0 \mathrm{H}), 5.85(\mathrm{ddt}, J$ $=16.1,10.9,7.3 \mathrm{~Hz}, 0 \mathrm{H}), 5.27(\mathrm{~s}, 1 \mathrm{H}), 5.23-5.13(\mathrm{~m}, 1 \mathrm{H}), 4.11(\mathrm{t}, J=$ $6.6 \mathrm{~Hz}, 1 \mathrm{H}), 3.85-3.71(\mathrm{~m}, 1 \mathrm{H}), 3.54-3.44(\mathrm{~m}, 3 \mathrm{H}), 2.37(\mathrm{~d}, J=7.3$ $\mathrm{Hz}, 1 \mathrm{H}), 2.09-1.93(\mathrm{~m}, 1 \mathrm{H}), 1.36(\mathrm{~s}, 1 \mathrm{H}), 1.22(\mathrm{t}, J=7.0 \mathrm{~Hz}, 4 \mathrm{H})$.

FAP498. Synthesized via general synthesis II described above (20.6 $\mathrm{mg}, 46 \%) .{ }^{1} \mathrm{H}$ NMR $\left(400 \mathrm{MHz}, \mathrm{CDCl}_{3}\right) \delta 7.52(\mathrm{~d}, J=13.4 \mathrm{~Hz}, 2 \mathrm{H})$, $7.40(\mathrm{~d}, J=7.2 \mathrm{~Hz}, 1 \mathrm{H}), 7.03(\mathrm{~d}, J=7.3 \mathrm{~Hz}, 1 \mathrm{H}), 6.93(\mathrm{~s}, 1 \mathrm{H}), 6.82$ $(\mathrm{s}, 1 \mathrm{H}), 5.91(\mathrm{dd}, J=17.3,10.8 \mathrm{~Hz}, 1 \mathrm{H}), 5.35-5.14(\mathrm{~m}, 2 \mathrm{H}), 4.54(\mathrm{~s}$, $1 \mathrm{H}), 4.35(\mathrm{~d}, J=20.0 \mathrm{~Hz}, 2 \mathrm{H}), 3.96(\mathrm{~s}, 2 \mathrm{H}), 3.62(\mathrm{~s}, 1 \mathrm{H}), 3.44(\mathrm{~s}$, $7 \mathrm{H}), 2.07(\mathrm{dt}, J=14.8,5.6 \mathrm{~Hz}, 1 \mathrm{H}), 1.36(\mathrm{~s}, 3 \mathrm{H}), 1.15(\mathrm{~s}, 6 \mathrm{H})$. HRMS calcd. for $\mathrm{C}_{31} \mathrm{H}_{33} \mathrm{~F}_{3} \mathrm{~N}_{2} \mathrm{O}_{3}(\mathrm{M}+\mathrm{H})$ 539.2443, found 539.2512 .

7-Hydroxy-9,9-dimethyl-10-(2-(trifluoromethyl)phenyl)anthracen-2(9H)-one. To a solution of 1-bromo-2(trifluoromethyl)benzene in $1 \mathrm{~mL}$ anhydrous THF was added tBuLi $(0.24 \mathrm{~mL}, 1.7 \mathrm{M})$ dropwise at $-78{ }^{\circ} \mathrm{C}$ and stirred for $1 \mathrm{~h}$ at that temperature. 3,6-bis((tert-butyldimethylsilyl)oxy)-10,10-dimethylanthracen-9(10H)-one $(50 \mathrm{mg}, 0.104 \mathrm{mmol})$ as a solution in $4 \mathrm{~mL}$ THF was added dropwise at $-78{ }^{\circ} \mathrm{C}$ and the reaction was warmed to room temperature and stirred for $3 \mathrm{~h}$. The reaction was quenched with $10 \mathrm{~mL} 1 \mathrm{M} \mathrm{HCl}$, stirred for 20 more minutes, and then $25 \mathrm{~mL}$ hexanes was added to form dark red crystals (76 mg, 52\%). LRMS calcd. for $\mathrm{C}_{23} \mathrm{H}_{17} \mathrm{~F}_{3} \mathrm{O}_{2}(\mathrm{M}+\mathrm{H})$ 383.38, found 383.4.

FAP555 Azide. Synthesized via general synthesis I described above (10 mg, 18\%). 1H NMR (500 MHz, Chloroform- $d$ ) $\delta 7.88$ (q, $J=7.3$ $\mathrm{Hz}, 1 \mathrm{H}), 7.69(\mathrm{dt}, J=24.5,7.8 \mathrm{~Hz}, 2 \mathrm{H}), 7.28(\mathrm{~s}, 3 \mathrm{H}), 7.19(\mathrm{dd}, J=$ 6.6, $4.2 \mathrm{~Hz}, 1 \mathrm{H}), 6.86-6.59$ (m, 4H), $6.31(\mathrm{~d}, J=9.7 \mathrm{~Hz}, 1 \mathrm{H}), 5.99$ $(\mathrm{dd}, J=17.4,11.0 \mathrm{~Hz}, 1 \mathrm{H}), 5.12(\mathrm{dt}, J=28.4,11.9 \mathrm{~Hz}, 2 \mathrm{H}), 4.37-$ $4.15(\mathrm{~m}, 2 \mathrm{H}), 1.74(\mathrm{~d}, J=13.1 \mathrm{~Hz}, 3 \mathrm{H}), 1.58(\mathrm{~s}, 3 \mathrm{H}), 1.27(\mathrm{~s}, 3 \mathrm{H})$, $1.15-1.06(\mathrm{~m}, 6 \mathrm{H})$.

FAP555. Synthesized via general synthesis II described above (4.4 mg, 46\%). 1H NMR (500 MHz, Chloroform- $d) \delta 7.88(\mathrm{q}, J=7.3 \mathrm{~Hz}$, $1 \mathrm{H}), 7.69(\mathrm{dt}, J=24.5,7.8 \mathrm{~Hz}, 2 \mathrm{H}), 7.28(\mathrm{~s}, 3 \mathrm{H}), 7.19(\mathrm{dd}, J=6.6,4.2$ $\mathrm{Hz}, 1 \mathrm{H}), 6.86-6.59(\mathrm{~m}, 4 \mathrm{H}), 6.31(\mathrm{~d}, J=9.7 \mathrm{~Hz}, 1 \mathrm{H}), 5.99(\mathrm{dd}, J=$ $17.4,11.0 \mathrm{~Hz}, 1 \mathrm{H}), 5.12(\mathrm{dt}, J=28.4,11.9 \mathrm{~Hz}, 2 \mathrm{H}), 4.37-4.15(\mathrm{~m}$, $2 \mathrm{H}), 2.12-1.89(\mathrm{~m}, 2 \mathrm{H}), 1.74(\mathrm{~d}, J=13.1 \mathrm{~Hz}, 3 \mathrm{H}), 1.58(\mathrm{~s}, 3 \mathrm{H}), 1.27$ $(\mathrm{s}, 3 \mathrm{H}), 1.15-1.06(\mathrm{~m}, 6 \mathrm{H})$. HRMS calcd. for $\mathrm{C}_{32} \mathrm{H}_{34} \mathrm{~F}_{3} \mathrm{NO}_{2}(\mathrm{M}+\mathrm{H})$ 522.2541 , found 522.2618

FAP573 Azide. Synthesized via general synthesis I described above (7.0 mg, 20\%). 1H NMR (400 MHz, $\left.\mathrm{CDCl}_{3}\right) \delta 7.72(\mathrm{~d}, J=8.9 \mathrm{~Hz}$, $1 \mathrm{H}), 7.44(\mathrm{~d}, J=9.8 \mathrm{~Hz}, 1 \mathrm{H}), 6.95(\mathrm{~d}, J=8.9 \mathrm{~Hz}, 1 \mathrm{H}), 6.84(\mathrm{~d}, J=1.6$ $\mathrm{Hz}, 2 \mathrm{H}), 6.36(\mathrm{~s}, 1 \mathrm{H}), 5.99(\mathrm{dd}, J=17.5,10.9 \mathrm{~Hz}, 1 \mathrm{H}), 5.21-5.03(\mathrm{~m}$, $2 \mathrm{H}), 4.21(\mathrm{t}, J=6.8 \mathrm{~Hz}, 2 \mathrm{H}), 2.22-1.93(\mathrm{~m}, 3 \mathrm{H}), 1.41(\mathrm{~s}, 3 \mathrm{H}), 1.25$ (s, $4 \mathrm{H}), 1.12(\mathrm{~s}, 5 \mathrm{H})$.

FAP573. Synthesized via general synthesis II described above (1.3 mg, 11\%). ${ }^{1} \mathrm{H}$ NMR $\left(400 \mathrm{MHz}, \mathrm{CDCl}_{3}\right) \delta 7.69(\mathrm{~d}, J=8.4 \mathrm{~Hz}, 1 \mathrm{H})$, $7.41(\mathrm{~d}, J=9.8 \mathrm{~Hz}, 1 \mathrm{H}), 6.98(\mathrm{~d}, J=10.2 \mathrm{~Hz}, 1 \mathrm{H}), 6.88(\mathrm{~s}, 1 \mathrm{H}), 6.82$ $(\mathrm{d}, J=11.3 \mathrm{~Hz}, 1 \mathrm{H}), 6.31(\mathrm{~s}, 1 \mathrm{H}), 5.92(\mathrm{dd}, J=17.3,10.8 \mathrm{~Hz}, 1 \mathrm{H})$, 5.34-5.18 (m, 2H), $4.29(\mathrm{~s}, 2 \mathrm{H}), 3.36(\mathrm{~s}, 1 \mathrm{H}), 2.34-2.24(\mathrm{~m}, 1 \mathrm{H})$, $2.10(\mathrm{~d}, J=8.6 \mathrm{~Hz}, 1 \mathrm{H}), 1.38(\mathrm{~s}, 3 \mathrm{H}), 1.17(\mathrm{~s}, 5 \mathrm{H})$. HRMS calcd. for $\mathrm{C}_{21} \mathrm{H}_{24} \mathrm{~N}_{2} \mathrm{O}_{3}(\mathrm{M}+\mathrm{H})$ 353.1787, found 353.1858.

Spectroscopic Materials and Methods. All spectroscopic measurements were performed in $20 \mathrm{mM}$ PBS, pH 7.4. Fluorescence spectra were recorded using a Photon Technology International Quanta Master $4 \mathrm{~L}$-format scan spectrofluorometer equipped with an LPS- 220B 75-W xenon lamp and power supply, A-1010B lamp housing with integrated igniter, switchable 814 photocounting/analog photomultiplier detection unit, and MD5020 motor driver. Samples were contained in $1 \mathrm{~cm} \times 1 \mathrm{~cm}$ quartz cuvettes during measurement (1.4 $\mathrm{mL}$ volume, Starna).

Quantum Yield Determination. All absorbance spectra were measured with an absorbance below 0.1. Quantum yield for each fluorophore was determined using the equation ( $\phi=$ quantum yield, $y$ $=$ emission intensity versus absorbance, and $\eta=$ refractive index):

$$
\phi_{\text {sample }}=\phi_{\text {standard }}\left(y_{\text {sample }} / y_{\text {standard }}\right)\left(\eta_{\text {sample }} / \eta_{\text {standard }}\right)^{2}
$$


FAP385 quantum yield was determined using harmaline in $0.005 \mathrm{M}$ $\mathrm{H}_{2} \mathrm{SO}_{4}(\phi=0.32)$ as a reference according to published procedures. ${ }^{66}$ FAP498 quantum yield was determined using fluorescein in $0.1 \mathrm{M}$ $\mathrm{NaOH}(\phi=0.91)$ as a reference according to published procedures. ${ }^{67}$ FAP555 and FAP573 quantum yield was determined using rhodamine 6G in ethanol $(\phi=0.94)$ as a reference according to published procedures. ${ }^{6}$

Cell Culture Procedures. HEK293T cells were maintained in exponential growth as a monolayer in Dulbecco's Modified Eagle Medium, high glucose, (DMEM, Invitrogen) supplemented with glutamax (Gibco), 10\% fetal bovine serum (FBS, Hyclone) and $1 \%$ nonessential amino acids (NEAA, Gibco), and incubated at $37^{\circ} \mathrm{C}$ in $5 \% \mathrm{CO}_{2}$. One day before imaging, the cells were passaged and plated in DMEM with glutamax (phenol red-free) supplemented with $10 \%$ FBS on poly D-lysine-coated 4-well Lab Tek borosilicate chambered coverglass slides (Nunc) at $1.8 \times 10^{5}$ per well.

ADH5 knockout HAP1 and genetically matched WT HAP1 cells were maintained in exponential growth as a monolayer in Iscove's Modified Dulbecco's Medium, high glucose, (IMDM, Invitrogen) supplemented with $10 \% \mathrm{FBS}$ and incubated at $37^{\circ} \mathrm{C}$ in $5 \% \mathrm{CO}_{2}$. One day before imaging, the cells were passaged and plated in DMEM with glutamax (phenol red-free) supplemented with $10 \%$ FBS on poly Dlysine-coated 4-well Lab Tek borosilicate chambered coverglass slides at $75 \%$ confluence.

ADH5 knockout MEF and genetically matched WT MEF cells were maintained in exponential growth as a monolayer in DMEM supplemented with $10 \% \mathrm{FBS}$ and incubated at $37{ }^{\circ} \mathrm{C}$ in $5 \% \mathrm{CO}_{2}$. One day before imaging, the cells were passaged and plated in DMEM with glutamax (phenol red-free) supplemented with $10 \%$ FBS on poly D-lysine-coated 4-well Lab Tek borosilicate chambered coverglass slides at $75 \%$ confluence.

Confocal Fluorescence Imaging Experiments. Confocal fluorescence imaging studies were performed with a Zeiss laser scanning microscope 710 with a $20 \times$ objective lens using Zen 2009 software (Carl Zeiss). FAP573 was excited using a 561 diode (for experiments in Figure 8) or $594 \mathrm{~nm} \mathrm{HeNe}$ laser (for all other experiments with FAP573), and emission was collected using a META detector between 573 to $682 \mathrm{~nm}$. The $561 \mathrm{~nm}$ laser was utilized on a Zeiss laser scanning microscope 710 located in the Molecular Imaging Center at UC Berkeley. FAP555 was excited using a $543 \mathrm{~nm} \mathrm{HeNe}$ laser, and emission was collected using a META detector between 560 to $669 \mathrm{~nm}$. FAP498 was excited using a $488 \mathrm{~nm} \mathrm{HeNe}$ laser, and emission was collected using a META detector between 493 to 630 $\mathrm{nm}$. FAP385 was excited with a $405 \mathrm{~nm}$ diode laser, and emission was collected using a META detector between 450 and $540 \mathrm{~nm}$. Hoechst 33342 was excited with a $405 \mathrm{~nm}$ diode laser, and emission was collected using a META detector between 400 and $450 \mathrm{~nm}$. BSS (136.9 mM NaCl, $5.37 \mathrm{mM} \mathrm{KCl}, 1.26 \mathrm{mM} \mathrm{CaCl}_{2}, 0.81 \mathrm{mM} \mathrm{MgSO}_{4}$, $0.44 \mathrm{mM} \mathrm{KH}_{2} \mathrm{PO}_{4}, 0.335 \mathrm{mM} \mathrm{Na}_{2} \mathrm{HPO}_{4}, 10 \mathrm{mM}$ PIPES; $\mathrm{pH}$ to 7.2 with $\mathrm{NaOH}$ ) was used as the imaging buffer for all confocal experiments. The cells were imaged at $37^{\circ} \mathrm{C}$ throughout the course of the experiment. Image analysis and quantification was performed using ImageJ (National Institutes of Health). Quantification of fluorescence intensity was performed using three fields of cells in the same well by generating a region of interest (ROI) around each image. The mean fluorescence intensity of each cell was measured (using "Measure" function) and averaged across the three ROIs. For each condition, multiple wells (reported as $\mathrm{n}$ ) were analyzed using this process, and the values were averaged across independent experiments for statistical analysis. Statistical analyses for multiple comparisons were performed using one-way ANOVA with the Bonferroni correction in the statistical analysis software, $\mathrm{R}$.

\section{ASSOCIATED CONTENT}

\section{S Supporting Information}

The Supporting Information is available free of charge on the ACS Publications website at DOI: 10.1021/jacs.6b12460.

Experimental details including additional selectivity assays, disruption of $\mathrm{ADH} 5$ in $\mathrm{HAP} 1$ cells, flow cytometry conditions and experiments, in vitro fluorescence response data of $6,9,10,14,17$, and FAP488, limit of detection, kinetics, cell viability, and NMR spectra (PDF)

\section{AUTHOR INFORMATION}

\section{Corresponding Author}

*chrischang@berkeley.edu

ORCID $\odot$

Christopher J. Chang: 0000-0001-5732-9497

Present Address

\#Department of Chemistry, Ursinus College, 601 E. Main Street, Collegeville, Pennsylvania 19426, United States.

\section{Author Contributions}

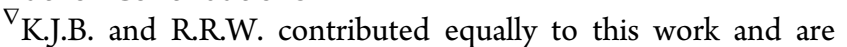
listed in alphabetical order.

\section{Notes}

The authors declare no competing financial interest.

\section{ACKNOWLEDGMENTS}

K.J.B. was partially supported by an NSF graduate fellowship. T.F.B. was partially supported by a Chemical Biology Training Grant from the NIH (T32 GM066698). C.J.C. is an Investigator of the Howard Hughes Medical Institute. We thank Alison Killilea and Carissa Tasto (UC Berkeley Tissue Culture Facility) for expert technical assistance.

\section{REFERENCES}

(1) Salthammer, T.; Mentese, S.; Marutzky, R. Chem. Rev. 2010, 110, 2536-2572.

(2) Puchtler, H.; Meloan, S. N. Histochemistry 1985, 82, 201-204.

(3) Liteplo, R. G.; Beauchamp, R.; Meek, M. E.; Chenier, R Formaldehyde (Concise International Chemical Assessment Documents); World Health Organization: Geneva, 2002.

(4) Tang, X.; Bai, Y.; Duong, A.; Smith, M. T.; Li, L.; Zhang, L. Environ. Int. 2009, 35, 1210-1224.

(5) He, R. Q.; Lu, J.; Miao, J. Y. Sci. China: Life Sci. 2010, 53, 13991404.

(6) Shi, Y.; Lan, F.; Matson, C.; Mulligan, P.; Whetstine, J. R.; Cole, P. A.; Casero, R. A.; Shi, Y. Cell 2004, 119, 941-953.

(7) Walport, L.; Hopkinson, R.; Chowdhury, R.; Schiller, R.; Ge, W.; Kawamura, A.; Schofield, C. Nat. Commun. 2016, 7, 11974.

(8) Hou, H.; Yu, H. Curr. Opin. Struct. Biol. 2010, 20, 739-748.

(9) Walport, L. J.; Hopkinson, R. J.; Schofield, C. J. Curr. Opin. Chem. Biol. 2012, 16, 525-534.

(10) Tibbetts, A. S.; Appling, D. R. Annu. Rev. Nutr. 2010, 30, 57-81.

(11) Heck, H. d. A.; Casanova-Schmitz, M.; Dodd, P. B.; Schachter, E. N.; Witek, T. J.; Tosun, T. AIHA J. 1985, 46, 1-3.

(12) Tong, Z.; Han, C.; Luo, W.; Wang, X.; Li, H.; Luo, H.; Zhou, J.; Qi, J.; He, R. Age 2013, 35, 583-596.

(13) Tulpule, K.; Dringen, R. J. Neurochem. 2013, 127, 7-21.

(14) Bosetti, C.; McLaughlin, J. K.; Tarone, R. E.; Pira, E.; La Vecchia, C. Ann. Oncol. 2008, 19, 29-43.

(15) Thompson, C. M.; Ceder, R.; Grafström, R. C. Toxicol. Lett. 2010, 193, 1-3.

(16) Staab, C. A.; Hellgren, M.; Höög, J. O. Cell. Mol. Life Sci. 2008, 65 (24), 3950-3960.

(17) Takeuchi, A.; Takigawa, T.; Abe, M.; Kawai, T.; Endo, Y.; Yasugi, T.; Endo, G.; Ogino, K. Bull. Environ. Contam. Toxicol. 2007, 79, $1-4$.

(18) Li, Q.; Sritharathikhun, P.; Motomizu, S. Anal. Sci. 2007, 23, 413-417.

(19) Yu, P. H.; Cauglin, C.; Wempe, K. L.; Gubisne-Haberle, D. Anal. Biochem. 2003, 318, 285-290. 
(20) Luo, W. H.; Li, H.; Zhang, Y.; Ang, C. Y. W. J. Chromatogr., Biomed. Appl. 2001, 753, 253-257.

(21) Kato, S.; Burke, P. J.; Koch, T. H.; Bierbaum, V. M. Anal. Chem. 2001, 73, 2992-2997.

(22) Chan, J.; Dodani, S. C.; Chang, C. J. Nat. Chem. 2012, 4, 973984.

(23) Lee, M. H.; Kim, J. S.; Sessler, J. L. Chem. Soc. Rev. 2015, 44, $4185-4191$.

(24) Chen, X.; Tian, X.; Shin, I.; Yoon, J. Chem. Soc. Rev. 2011, 40, $4783-4804$.

(25) Yang, Y.; Zhao, Q.; Feng, W.; Li, F. Chem. Rev. 2013, 113, 192270.

(26) Wang, J.; Karpus, J.; Zhao, B. S.; Luo, Z.; Chen, P. R.; He, C. Angew. Chem. 2012, 124, 9790-9794.

(27) Michel, B. W.; Lippert, A. R.; Chang, C. J. J. Am. Chem. Soc. 2012, 134, 15668 .

(28) Zheng, K.; Lin, W.; Tan, L.; Chen, H.; Cui, H. Chem. Sci. 2014, $5,3439-3448$.

(29) Chaves-Ferreira, M.; Albuquerque, I. S.; Matak-Vinkovic, D.; Coelho, A. C.; Carvalho, S. M.; Saraiva, L. M.; Romao, C. C.; Bernardes, G. J. L. Angew. Chem., Int. Ed. 2015, 54, 1172-1175.

(30) Wilson, J. L.; Fayad Kobeissi, S.; Oudir, S.; Haas, B.; Michel, B.; Dubois Rande, J.-L.; Ollivier, A.; Martens, T.; Rivard, M.; Motterlini, R.; Foresti, R. Chem. - Eur. J. 2014, 20, 14698-14704.

(31) Wang, T.; Douglass, E. F.; Fitzgerald, K. J.; Spiegel, D. A. J. Am. Chem. Soc. 2013, 135, 12429-12433.

(32) Brewer, T. F.; Chang, C. J. J. Am. Chem. Soc. 2015, 137, 1088610889 .

(33) Liu, W.; Truillet, C.; Flavell, R. R.; Brewer, T. F.; Evans, M. J.; Wilson, D. M.; Chang, C. J. Chem. Sci. 2016, 7, 5503-5507.

(34) Roth, A.; Li, H.; Anorma, C.; Chan, J. J. Am. Chem. Soc. 2015, 137, 10890-10893.

(35) Tang, Y.; Kong, X.; Xu, A.; Dong, B.; Lin, W. Angew. Chem., Int. Ed. 2016, 55, 3356-3359.

(36) Xu, J.; Zhang, Y.; Zeng, L.; Liu, J.; Kinsella, J. M.; Sheng, R. Talanta 2016, 160, 645-652.

(37) Xie, Z.; Ge, J.; Zhang, H.; Bai, T.; He, S.; Ling, J.; Sun, H.; Zhu, Q. Sens. Actuators, B 2017, 241, 1050-1056.

(38) Li, J.-B.; Wang, Q.-Q.; Yuan, L.; Wu, Y.-X.; Hu, X.-X.; Zhang, X.-B.; Tan, W. Analyst 2016, 141, 3395-3402.

(39) He, L.; Xueling, Y.; Liu, Y.; Kong, X.; Lin, W. Chem. Commun. 2016, 52, 4029-4032.

(40) Lee, Y. H.; Tang, Y.; Verwilst, P.; Lin, W.; Kim, J. S. Chem. Commun. 2016, 52, 11247-11250.

(41) He, L.; Yang, X.; Ren, M.; Kong, X.; Liu, Y.; Lin, W. Chem. Commun. 2016, 52, 9582-9585.

(42) Tang, Y.; Kong, X.; Liu, Z.; Xu, A.; Lin, W. Anal. Chem. 2016, 88, 9359-9363.

(43) Liu, C.; Jiao, X.; He, S.; Zhao, L.; Zeng, X. Dyes Pigm. 2017, 138, 23-29.

(44) Urano, Y.; Kamiya, M.; Kanda, K.; Ueno, T.; Hirose, K.; Nagano, T. J. Am. Chem. Soc. 2005, 127, 4888-4894.

(45) Kim, D.; Sambasivan, S.; Nam, H.; Kim, K. H.; Kim, J. Y.; Joo, T.; Lee, K.-H.; Kim, K.-T.; Ahn, K. H. Chem. Commun. 2012, 48, 6833-6835.

(46) Aw, J.; Shao, Q.; Yang, Y.; Jiang, T.; Ang, C.; Xing, B. Chem. Asian J. 2010, 5, 1317-1321.

(47) Bedia, C.; Camacho, L.; Casas, J.; Abad, J. L.; Delgado, A.; Van Veldhoven, P. P.; Fabriàs, G. ChemBioChem 2009, 10, 820-822.

(48) Zhou, W.; Valley, M. P.; Shultz, J.; Hawkins, E. M.; Bernad, L.; Good, T.; Good, D.; Riss, T. L.; Klaubert, D. H.; Wood, K. V. J. Am. Chem. Soc. 2006, 128, 3122-3123.

(49) Goddard-Borger, E. D.; Stick, R. V. Org. Lett. 2007, 9, 37973800.

(50) Miller, E. W.; Tulyathan, O.; Isacoff, E. Y.; Chang, C. J. Nat. Chem. Biol. 2007, 3, 263-267.

(51) Lavis, L. D.; Chao, T.-Y.; Raines, R. T. Chem. Sci. 2011, 2, 521.

(52) Au-Yeung, H. Y.; New, E. J.; Chang, C. J. Chem. Commun. 2012, $48,5268-5270$
(53) Kamiya, M.; Urano, Y.; Ebata, N.; Yamamoto, M.; Kosuge, J.; Nagano, T. Angew. Chem., Int. Ed. 2005, 44, 5439.

(54) Kobayashi, T.; Urano, Y.; Kamiya, M.; Ueno, T.; Kojima, H.; Nagano, T. J. Am. Chem. Soc. 2007, 129, 6696.

(55) Kamiya, M.; Kobayashi, H.; Hama, Y.; Koyama, Y.; Bernardo, M.; Nagano, T.; Choyke, P. L.; Urano, Y. J. Am. Chem. Soc. 2007, 129, $3918-3929$.

(56) Bartra, M.; Romea, P.; Urpí, F.; Vilarrasa, J. Tetrahedron 1990, 46, 587-594.

(57) Alam, R.; Raducan, M.; Eriksson, L.; Szabó, K. J. Org. Lett. 2013, $15,2546-2549$.

(58) Jung, M. E.; Piizzi, G. Chem. Rev. 2005, 105, 1735-1766.

(59) Grimm, J. B.; Sung, A. J.; Legant, W. R.; Hulamm, P.; Matlosz, S. M.; Betzig, E.; Lavis, L. D. ACS Chem. Biol. 2013, 8, 1303-1310.

(60) Kalapos, M. P. Diabetes Res. Clin. Pract. 2013, 99, 260-271.

(61) Pontel, L. B.; Rosado, I. V.; Burgos-Barragan, G.; Garaycoechea, J. I.; Yu, R.; Arends, M. J.; Chandrasekaran, G.; Broecker, V.; Wei, W.; Liu, L.; Swenberg, J. A.; Crossan, G. P.; Patel, K. J. Mol. Cell 2015, 60, 177-188.

(62) Lippert, A. R.; Van De Bittner, G. C.; Chang, C. J. Acc. Chem. Res. 2011, 44, 793-804.

(63) Brewer, T. F.; Garcia, F. J.; Onak, C. S.; Carroll, K. S.; Chang, C. J. Annu. Rev. Biochem. 2015, 84, 765-790.

(64) Raducan, M.; Alam, R.; Szabó, K. J. Angew. Chem., Int. Ed. 2012, 51, 13050-13053.

(65) Matsuzaki, H.; Kamiya, M.; Iwatate, R. J.; Asanuma, D.; Watanabe, T.; Urano, Y. Bioconjugate Chem. 2016, 27, 973-981.

(66) Pardo, A.; Reyman, D.; Poyato, J. M. L.; Medina, F. J. Lumin. 1992, 51, 269.

(67) Porrès, L.; Holland, A.; Palsson, L. O.; Monkman, A. P.; Kemp, C.; Beeby, A. J. Fluoresc. 2006, 16, 267.

(68) Fischer, M.; Georges, J. Chem. Phys. Lett. 1996, 260, 115. 